\title{
Methane emissions from dairy lagoons in the western United States
}

\author{
A. B. Leytem, ${ }^{* 1}$ D. L. Bjorneberg, ${ }^{*}$ A. C. Koehn, ${ }^{*}$ L. E. Moraes, $†$ E. Kebreab, $\ddagger$ and R. S. Dungan* \\ *USDA-Agricultural Research Service, Northwest Irrigation and Soils Research Laboratory, Kimberly, ID 83341 \\ †Department of Animal Sciences, The Ohio State University, Columbus 43210 \\ ‡Department of Animal Science, University of California-Davis, Davis 95616
}

\section{ABSTRACT}

Methane generation from dairy liquid storage systems is a major source of agricultural greenhouse gas emissions. However, little on-farm research has been conducted to estimate and determine the factors that may affect these emissions. Six lagoons in south-central Idaho were monitored for $1 \mathrm{yr}$, with $\mathrm{CH}_{4}$ emissions estimated by inverse dispersion modeling. Lagoon characteristics thought to contribute to $\mathrm{CH}_{4}$ emissions were also monitored over this time period. Average emissions from the lagoons ranged from 30 to $126 \mathrm{~kg} / \mathrm{ha}$ per day or 22 to $517 \mathrm{~kg} / \mathrm{d}$. Whereas we found a general trend for greater emissions during the summer, when temperatures were greater, events such as pumping, rainfall, freeze or thaw of lagoon surfaces, and wind significantly increased $\mathrm{CH}_{4}$ emissions irrespective of temperature. Lagoon physicochemical characteristics, such as total solids, chemical oxygen demand, and volatile solids, were highly correlated with emission. Methane prediction models were developed using volatile solids, wind speed, air temperature, and $\mathrm{pH}$ as independent variables. The US Environmental Protection Agency methodology for estimating $\mathrm{CH}_{4}$ emissions from manure storage was used for comparison of on-farm $\mathrm{CH}_{4}$ emissions from 1 of the lagoon systems. The US Environmental Protection Agency method underestimated $\mathrm{CH}_{4}$ emissions by $48 \%$. An alternative methodology, using volatile solids degradation factor, provided a more accurate estimate of annual emissions from the lagoon system and may hold promise for applicability across a range of dairy lagoon systems in the United States.

Key words: emission, methane, manure, inverse dispersion

\section{INTRODUCTION}

The latest US Environmental Protection Agency (USEPA) greenhouse gas (GHG) inventory (USEPA,

Received February 21, 2017.

Accepted April 9, 2017.

${ }^{1}$ Corresponding author: April.leytem@ars.usda.gov 2016b) estimates that agriculture accounts for $9 \%$ of total GHG emissions in the United States. The percentage of agricultural GHG emissions from enteric $\mathrm{CH}_{4}$ production and manure management are 28.6 and $13.7 \%$, respectively. The majority of enteric $\mathrm{CH}_{4}$ produced is estimated to be from beef cattle $(71 \%)$, whereas dairy cattle contributed $26 \%$; however, $\mathrm{CH}_{4}$ production from dairy manure management is estimated to be the largest fraction of $\mathrm{CH}_{4}$ produced from manure at $53 \%$, followed by swine at $37 \%$. The majority of these manure emissions are generated from the storage of liquid manures in anaerobic lagoons.

A large body of work exists related to estimation of enteric $\mathrm{CH}_{4}$ production by cattle and potential mitigation strategies (e.g., Kebreab et al., 2008; Sejian et al., 2011; Powers et al., 2014); however, $\mathrm{CH}_{4}$ production from manure storage is not well studied and there may be large discrepancies between inventory estimates and actual on-farm emissions. Some research indicates that the USEPA and Intergovernmental Panel on Climate Change methodologies may be underestimating $\mathrm{CH}_{4}$ contributions from liquid dairy manure storage by up to $130 \%$ (Lory et al., 2010; Baldé et al., 2016). One of the reasons for these large discrepancies is that the emission factors developed for inventory purposes were based on limited data that may not represent the variety of manure storage conditions found on US dairies (Bryant et al., 1976; Morris 1976; Mangino et al., 2001).

Approximately 17 on-farm studies (21 lagoons) have been published related to $\mathrm{CH}_{4}$ production from dairy liquid manure storage (Table 1). Only 8 of these studies were conducted on dairies located in the United States, and another 4 were on Canadian dairies, which could represent both weather characteristics and management practices in certain regions of US dairy production. Approximately half of the studies have provided an annual average $\mathrm{CH}_{4}$ emission factor, whereas the remaining studies only looked at emissions during shorter intervals. The emission rates reported in the literature vary widely, with a range of 12 to $2,030 \mathrm{~kg}$ of $\mathrm{CH}_{4} /$ ha per day and 4.7 to $1,028 \mathrm{~g} /$ head per day. This range in values indicates the diversity of the different manure-management systems that can be found in dairy 
production and originates from factors such as fraction of manure stored as a liquid, effects of enhanced solid separation, length of storage, temperature, agitation, and crust formation. In addition, the influence of cattle diets, the addition of materials such as spilled feed, milk, and cleaning agents that are washed into storage areas, and the amount of inoculum remaining in storage may have an effect.

The goal of the current study was to add to the body of knowledge related to $\mathrm{CH}_{4}$ emissions from storage of liquid manure on dairy production facilities in the western United States. In particular, we aimed to study seasonal trends in emissions, relate emissions measured on the farm with lagoon liquid characteristics, and compare these emissions with estimates derived with current inventory methodology.

\section{MATERIALS AND METHODS}

\section{Farm Descriptions}

During September 2010 to November 2015, 6 dairy lagoons were selected for monitoring of $\mathrm{CH}_{4}$ emissions (Table 2). These farms were selected to represent manure-handling techniques typically found on a western US dairy and based on farm layout and the ability to separate the lagoon emissions from the rest of the farm. They were also situated in areas where no other upwind $\mathrm{CH}_{4}$ sources could contribute to measured $\mathrm{CH}_{4}$ concentrations. This enabled us to select lagoons that would not have any interference from internal or external $\mathrm{CH}_{4}$ sources. In addition, farms were selected to represent a variety of sizes, ranging from less than 1,000 cows to greater than 5,000 cows. Five of the dairies were dry lot dairies where cows were housed in pens and the majority of manure was stored as a solid. In these systems, manure from the milking parlor and holding areas flowed into a lagoon system, which typically consisted of 1 or more settling basins to separate out some of the solids followed by a larger lagoon. These lagoons were typically pumped out in the spring and fall onto the surrounding cropland; however, the sludge remaining in the ponds was typically not removed. The settling basins were cleaned out on an infrequent basis, but in many cases they were not cleaned out more than once a year at the most. One dairy was a freestall dairy where the lactating cows were housed in naturally ventilated barns and the manure from the barns was cleaned out by flushing the alleyways behind the freestalls. The wash water from the milking parlor and holding area on this dairy also flowed into the lagoon system. The dairy manure-handling systems varied by farm and are described below.
- D1: A dry lot dairy with manure storage comprised of 3 settling basins and a main lagoon. The main lagoon was monitored.

- D2: A dry lot dairy with manure storage comprised of 4 settling basins and a main lagoon. The main lagoon was monitored.

- D3: A dry lot dairy that was recently converted to a heifer operation; however, during the last quarter of the study lactating animals were on the farm. The lagoon system consisted of 5 settling basins and a main lagoon. The main lagoon and settling basins were monitored.

- D4: A freestall dairy utilizing a flush system with the manure-storage system consisting of a screen separator, 3 settling basins, 3 main lagoons, and a satellite lagoon. The satellite lagoon was monitored.

- D5: A dry lot dairy composed of a concrete settling cell and 3 lagoons. The final lagoon in the series was monitored.

- D6: A dry lot dairy comprised of 1 settling basin and a main lagoon. The main lagoon and settling basin were monitored.

\section{Methane Concentration and Wind Measurements}

Initially, lagoons were monitored seasonally (D1 and D2), but as more resources became available monitoring times were increased to better capture annual variations in emissions (D3-D6). The concentration of $\mathrm{CH}_{4}$ was measured using open-path Fourier transform infrared spectrometry (OP/FTIR; Griffiths et al., 2009; Shao et al., 2010). One OP/FTIR (Air Sentry, Cerex Monitoring Solutions, Atlanta, GA, or ABB-Bomem MB-100, MDA, Atlanta, GA) was located either across the downwind edge/corner (D1, D3, D4) or on the downwind bank (D2, D5, D6) of the lagoon, with a sensor height at $1.7 \mathrm{~m}$ and path lengths ranging from 130 to $240 \mathrm{~m}$. On D3 and D6, the position of the OP/ FTIR enabled monitoring of either the settling basins or the lagoons depending on wind direction. Spectra were acquired continuously and averaged over 5-min intervals. Background concentrations were measured at each dairy for several days at the onset of the study as well as at a remote (nonagricultural affected) location for comparison. Experiments performed with the OP/ FTIR units demonstrated that background concentrations were very stable and did not fluctuate daily (CV $=4 \%$ over a 4 -d period with 1,049 measurements and a change in background concentration of $\leq 0.3 \mathrm{ppm}$ ). In addition, the on-farm concentration data at each location was filtered for wind directions to isolate times when no upwind source of $\mathrm{CH}_{4}$ was present to verify 
METHANE EMISSIONS FROM LAGOONS

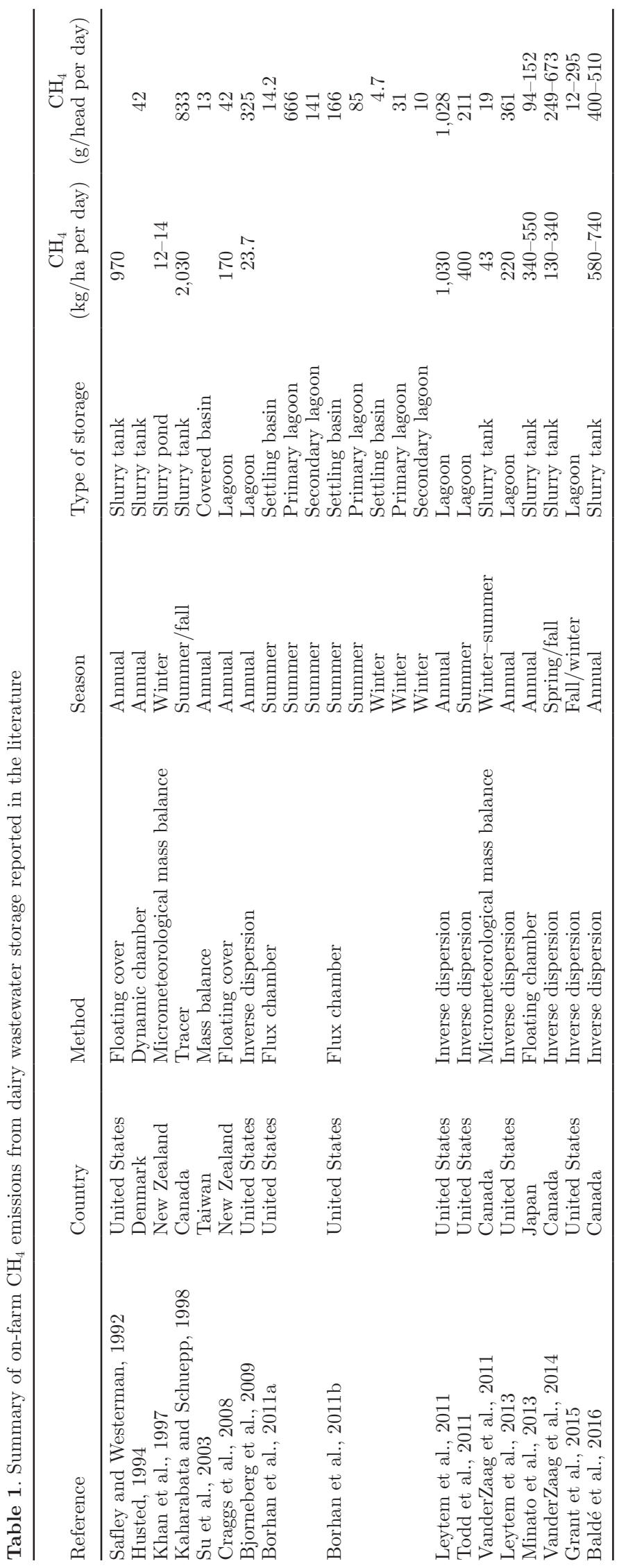


that background concentrations were consistent over time. Quantitative determinations of $\mathrm{CH}_{4}$ concentrations were performed by partial least squares regression of the OP/FTIR spectra (Griffiths et al., 2009; Shao et al., 2011, 2013), and the detection limit of $\mathrm{CH}_{4}$ was less than $0.01 \mathrm{ppm}$. Concentration data were processed to produce 15-min average mixing-ratio concentrations at the source areas $(\boldsymbol{C})$.

The wind environment at the dairy was described by simple Monin-Obukhov similarity theory relationships defined by $u^{*}, L, z_{0}$, and $\beta$, as provided by 3 -dimensional sonic anemometers (RM Young Model 81000 ultrasonic anemometer, Traverse City, MI), where $u^{*}$ is the friction velocity, $L$ is the Obukhov stability length, $z_{0}$ is the surface roughness length, and $\beta$ is wind direction. Flesch et al. (2004) details how these parameters were calculated from a sonic anemometer. The sonic anemometer was located on a 3-m tower at each lagoon, where there were minimal flow disturbances from structures upwind, to capture a more idealized wind flow of the area, as suggested by Flesch et al. (2005a). Wind parameters were calculated for each 15 -min period (corresponding to $C$ observations). A meteorological station was also located at each lagoon to record barometric pressure, air temperature, wind direction, and wind speed (all at $2 \mathrm{~m}$ ) during the experimental period.

\section{Emissions Calculations}

We used WindTrax 2.0 software (Thunder Beach Scientific, Nanaimo, Canada) to determine lagoon emission rates, which combines the backward Lagrangian stochastic inverse-dispersion technique described by Flesch et al. (2004), with an interface allowing sources and sensors to be conveniently mapped. This technique has been used in several controlled-release studies to determine emissions from barn and lagoon source areas and was shown to provide estimates of emissions within $15 \%$ of actual emissions (McGinn et al., 2009; Gao et al., 2010; Ro et al., 2013). For a detailed description of the backward Lagrangian stochastic technique, see
Flesch et al. (2005a,b, 2007). The lagoons and settling basins were mapped using available satellite imagery and on-farm global positioning system data. Emission estimates $(\mathrm{kg} / \mathrm{ha}$ per day and $\mathrm{kg} / \mathrm{d})$ were calculated using $\mathrm{n}=50,000$ trajectories and fixed background concentrations. Emissions from the settling basins were determined using the method stated above; however, the lagoons at both dairies (D3 and D6) and the cattle housing at D6 were also included as source areas in the model and set at an average emission rate to account for any $\mathrm{CH}_{4}$ contributions from those sources (Flesch et al., 2009). The lagoon emission rates were determined from the data generated during the same time periods, and the emission rates from the housing, which would be mainly enteric $\mathrm{CH}_{4}$ production from the cattle, were calculated using the approach of Rotz and Chianese (2009) and set at $100 \mathrm{~kg} / \mathrm{d}$ for the housing area.

As good emissions estimates are dependent on utilizing data that do not violate the Monin-Obukhov similarity theory assumptions (i.e., low winds, extreme stabilities, wind profile errors), data were filtered. We (1) removed periods where $u^{*} \leq 0.10 \mathrm{~m} / \mathrm{s}$ (low wind conditions), (2) removed periods where $|L| \leq 5 \mathrm{~m}$ (strongly stable/unstable atmosphere;), and (3) removed periods where $z_{0} \geq 1 \mathrm{~m}$ (associated with errors in wind profile; Ro et al., 2013; Flesch et al., 2014).

Due to the location of the concentration sensors and other source areas on the site, for some wind directions, measurements of the downwind concentrations may not sample enough of the farm plume, which can lead to uncertainty in emission estimates (Flesch et al. 2005b). Additionally, cross contamination might occur due to emissions from other source areas on the farm. Therefore, we filtered out data when the wind was either not within $\pm 40^{\circ}$ perpendicular to the OP/FTIR path length or from areas where there could be other $\mathrm{CH}_{4}$ sources (such as cattle pens, manure piles) to ensure that the concentration sensors were measuring gases from the source areas of interest only. The 15-min emission estimates were then averaged for each hour, with hourly values averaged over a day. Monthly averages

Table 2. Characteristics of the dairies used to determine on-farm lagoon methane emissions in south-central Idaho

\begin{tabular}{|c|c|c|c|c|c|c|}
\hline Dairy & Housing & $\begin{array}{l}\text { Size class of } \\
\text { operation (no. of } \\
\text { cattle) }\end{array}$ & Lagoon water source & Surface area $\left(\mathrm{m}^{2}\right)$ & Depth (m) & $\begin{array}{l}\text { Monitoring } \\
\text { periods }(\mathrm{mo} / \mathrm{d})\end{array}$ \\
\hline D1 & Dry lot & $1,000-5,000$ & Parlor wash water & 26,628 & $2.4-2.7$ & $9 / 10-6 / 11$ \\
\hline D2 & Dry lot & $5,000-10,000$ & Parlor wash water & 47,398 & 1.5 & $12 / 10-6 / 11$ \\
\hline D3 & Dry lot & $1,000-5,000$ & Parlor wash water & $19,621-23,237$ & $1.2-1.9$ & $6 / 12-5 / 13$ \\
\hline D4 & Freestall & $5,000-10,000$ & $\begin{array}{l}\text { Flush system from barn and parlor } \\
\text { wash water }\end{array}$ & $4,005-13,220$ & $0.9-1.6$ & $5 / 12-5 / 13$ \\
\hline D5 & Dry lot & $1,000-5,000$ & Parlor wash water & $1,300-3,373$ & $0.3-1.3$ & $7 / 13-11 / 14$ \\
\hline D6 & Dry lot & $<1,000$ & Parlor wash water and runoff & 2,101 & $0.3-0.9$ & $11 / 14-11 / 15$ \\
\hline
\end{tabular}


were determined by averaging all available daily emission values collected during that month.

\section{Lagoon Sampling and Analyses}

An intensive lagoon sampling campaign was conducted simultaneously with the emissions monitoring to determine spatial and temporal changes in lagoon properties that could be associated with $\mathrm{CH}_{4}$ emissions. Measurements included chemical oxygen demand (COD), TS, volatile solids (VS), pH, temperature, dissolved oxygen (DO), and specific conductivity. A detailed description of the study can be found in Leytem et al. (2017), a brief description follows.

Lagoons were sampled $(500 \mathrm{~mL})$ every 2 to $3 \mathrm{wk}$ on a grid with the number of sampling points (4 to 10) related to the size of the lagoon and distributed as evenly as possible across the lagoon surface. Lagoon depth was determined with a sampling rod that was marked for depth. The rod was allowed to sit on the top of the sludge layer at the bottom of the lagoon to determine the depth of the water column. This rod was connected to a container with a retractable lid to collect samples at specific depths. When lagoons were deeper than $1 \mathrm{~m}$ (D1-D4), samples were collected from the surface (0.15 $\mathrm{m}$ below surface) and $0.3 \mathrm{~m}$ above the top of the sludge layer at each sampling location; otherwise only surface samples were collected.

Immediately after collection, a $125-\mathrm{mL}$ subsample was taken and mixed with $1 \mathrm{~mL}$ of concentrated sulfuric acid to stabilize the sample for COD analysis. All samples were transferred to the laboratory in coolers, then stored under refrigeration at $5^{\circ} \mathrm{C}$ and processed within $36 \mathrm{~h}$. In addition to collecting samples for analysis, the lagoon temperature, $\mathrm{pH}, \mathrm{DO}$, and specific conductivity were determined in situ with a YSI 556 Multiprobe System (YSI Inc., Yellow Springs, OH) at each sampling location and depth; these measurements were typically made in late morning or early afternoon. All samples were allowed to come to room temperature and thoroughly mixed before subsampling and analysis. Analyses were performed for TS and VS according to standard methods $2540 \mathrm{~B}$ and 2540E, respectively (Eaton et al., 2005), and COD according to USEPA method 410.4 (USEPA, 1993). As we found no significant differences spatially or with depth at each lagoon (Leytem et al., 2017), the data were averaged (across location and depth) to produce 1 daily value. The coefficient of variation in COD at each sampling time ranged from 1 to 110 , with $62 \%$ of values being less than $10 \%$ and only 1 value over $40 \%$. The coefficient of variation of TS ranged from 1 to $46 \%$, with $87 \%$ being less than 10\%; for VS the coefficient of variation ranged from 1 to $49 \%$, with $90 \%$ being less than $10 \%$. The higher coefficient of variation values were association with time periods when the lagoons were being pumped out or agitated in some other way (filling, irrigation, and so on).

\section{USEPA $\mathrm{CH}_{4}$ Emissions Estimates}

We calculated the USEPA estimated emissions for D6 based on the "Methodology for estimating $\mathrm{CH}_{4}$ and $\mathrm{N}_{2} \mathrm{O}$ emissions from manure management" (USEPA, 2016a) to determine how well on-farm measurements compared with calculated inventory estimates. This was done only for D6, as we had the most continuous emissions data from this dairy and we were able to obtain measurements from all of the stored liquid generated on the farm. The $\mathrm{CH}_{4}$ generated each month was calculated as

$$
\mathrm{CH}_{4}=\mathrm{VS} \times \mathrm{B}_{\mathrm{o}} \times \mathrm{MCF} \times 0.662 \times \mathrm{MDP},
$$

where $\mathrm{CH}_{4}$ is emissions in kilograms per month, VS is the amount of VS entering the lagoon each month $(\mathrm{kg}), \mathrm{B}_{\mathrm{o}}$ is the maximum $\mathrm{CH}_{4}$-producing capacity of the manure $\left(\mathrm{m}^{3}\right.$ of $\mathrm{CH}_{4} / \mathrm{kg}$ of $\left.\mathrm{VS}\right), \mathrm{MCF}$ is the methane conversion factor, 0.662 is the density of $\mathrm{CH}_{4}$ at $25^{\circ} \mathrm{C}$ ( $\mathrm{kg}$ of $\mathrm{CH}_{4} / \mathrm{m}^{3}$ of $\mathrm{CH}_{4}$ ), and the MDP is the management and design practices factor (0.8). The estimated VS excreted for dairy cows in Idaho were obtained from Table A-206 (USEPA, 2016a; 2,902 kg/cow per year) and $\mathrm{B}_{\mathrm{O}}$ for dairy cows was obtained from Table A-204 (USEPA, 2016a; $0.24 \mathrm{~m}^{3}$ of $\mathrm{CH}_{4} / \mathrm{kg}$ of VS). The MCF was calculated each month based on average ambient air temperature measured at the lagoon for the month with the equation:

$$
\mathrm{MCF}=\exp \left[\mathrm{E}\left(\mathrm{T}_{2}-\mathrm{T}_{1}\right) / \mathrm{RT}_{1} \mathrm{~T}_{2}\right],
$$

where $\mathrm{E}$ is the activation energy constant $(15,175 \mathrm{cal} /$ $\mathrm{mol}), \mathrm{T}_{2}$ is the average ambient air temperature $(\mathrm{K})$ for the month, $\mathrm{T}_{1}$ is $303.15 \mathrm{~K}$, and $\mathrm{R}$ is the ideal gas constant $(1.987 \mathrm{cal} / \mathrm{K}$ per mole). A minimum temperature of $5^{\circ} \mathrm{C}$ was used due to the biological activity in the lagoon which keeps the temperature above freezing.

The USEPA calculation assumes that lagoons are fully emptied in October of each year and start accumulating VS in November; thus, we started the calculation in November and ran it through the following November and compared this with on-farm data from December through November. The VS consumed during each month were subtracted from total available VS for the next month's calculation according to Mangino et al. (2001). We assumed that $10 \%$ of VS 
generated by the lactating cattle on the farm went to the lagoon, based on estimates of Saggar et al. (2004), along with an estimate of the time that the cattle spent in the holding area and milking parlor each day. As the USEPA does not account for the use of settling basins, all the liquid was assumed to go into the lagoon for calculation purposes, and this was compared with the combined measured emissions from the settling basin and lagoon. We also calculated an annual $\mathrm{CH}_{4}$ emission estimate based on equation 1 and using the values stated above with the exception of the MCF, which we obtained from Table A-210 (USEPA, 2016a) for an anaerobic lagoon in Idaho (69\%).

\section{Emissions Estimate Using Lory et al. (2010) Methodology}

Lory et al. (2010) argued that the USEPA method would likely underestimate actual emissions from uncovered anaerobic dairy lagoons, particularly in colder climates. Those authors concluded that a large part of the discrepancy would be related to the $\mathrm{B}_{\mathrm{o}}$ factor that had been derived from anaerobic digesters, which would not necessarily reflect the VS degradation found in uncovered anaerobic lagoons, coupled with a flawed MCF calculation. They instead proposed using a volatile solids degradation factor (VSDF) that was based on published research from uncovered anaerobic dairy lagoons coupled with a factor estimating the amount of $\mathrm{CH}_{4}$ produced from the VS destroyed. We estimated $\mathrm{CH}_{4}$ emissions from D6 based on this methodology as

$$
\mathrm{CH}_{4}=\mathrm{VS} \times \mathrm{VSDF} \times \mathrm{B}^{\prime} \times 0.662,
$$

where $\mathrm{CH}_{4}$ is the emissions in kilograms per year, VS is the total volatile solids excreted going to the lagoon $(\mathrm{kg})$, VSDF is the fraction of VS broken down in storage ( $\mathrm{kg}$ of VS destroyed/ $\mathrm{kg}$ of VS added; 0.57), $\mathrm{B}^{\prime}$ is the volume of $\mathrm{CH}_{4}$ generated on a VS destroyed basis for the lagoon $\left(\mathrm{m}^{3}\right.$ of $\mathrm{CH}_{4} / \mathrm{kg}$ of VS destroyed; $0.45-0.85$ ), and 0.662 is the density of $\mathrm{CH}_{4}$ at $25^{\circ} \mathrm{C}$ ( $\mathrm{kg}$ of $\mathrm{CH}_{4} / \mathrm{m}^{3}$ of $\mathrm{CH}_{4}$ ). The estimated VS excreted for dairy cows in Idaho were obtained from Table A-206 (USEPA, 2016a), as described above $(2,902 \mathrm{~kg} /$ cow per year), and we assumed 10\% of excreted VS went to the lagoon system.

\section{Statistical Analysis}

Linear regression was performed with SAS (ver. 9.3; SAS Institute Inc., Cary, $\mathrm{NC}$ ) to relate daily $\mathrm{CH}_{4}$ emissions estimates to both meteorological parameters and lagoon physicochemical characteristics. As lagoon characteristics changed predictably and slowly over time (Leytem et al., 2017), daily lagoon physicochemical characteristics were calculated by linear interpolation between sampled days.

Mixed effects models were developed to predict $\mathrm{CH}_{4}$ emissions ( $\mathrm{kg} /$ ha per day) using independent variables describing lagoon and meteorological characteristics: lagoon-specific conductivity $(\mathrm{mS} / \mathrm{cm})$, VS $(\mathrm{mg} / \mathrm{L})$, TS $(\mathrm{mg} / \mathrm{L}), \mathrm{COD}(\mathrm{mg} / \mathrm{L})$, lagoon $\mathrm{pH}$, wind speed $(\mathrm{m} / \mathrm{s})$, and mean air temperature $\left({ }^{\circ} \mathrm{C}\right)$. To avoid multicollinearity, 4 pools of independent variables were created for which the correlation of any pair of independent variables, within a pool, was smaller than 0.5 . For each of the 4 pools, all possible models (i.e., models resulting from all combinations of independent variables) were fitted and the model with the smallest Akaike information criterion (AIC; Sakamoto et al., 1986) was selected. The final selected models (the best model from each pool) were subjected to a 10 -fold cross validation for the determination of the mean square prediction error (MSPE) with independent data (Hastie et al., 2009). In short, the data were randomly divided into 10 folds of similar size. Ten training sets were created by leaving each 1 of the 10 folds out. The 10 testing sets were the folds that were left out of each of the 10 training sets. The following linear mixed effects model was used as the framework:

$$
y_{i j}=\mathbf{x}_{i j}^{T} \boldsymbol{\beta}+\alpha_{i}+\varepsilon_{i j},
$$

where $y_{i j}$ is the $j$ th record $\left(j=1, \ldots, m_{i}\right)$ of $\mathrm{CH}_{4}$ emissions in the $i$ th dairy $(i=1, \ldots, 6), \mathbf{x}_{i j}$ is the corresponding vector of independent variables to be selected, $\boldsymbol{\beta}$ is the vector of fixed regression coefficients, $\alpha_{i}$ is the random effect of the $i$ th dairy [assumed $N(0, \tau)$ ], and $\varepsilon_{i j}$ is the error [assumed $N\left(0, \sigma^{2}\right)$ ] with $N$ denoting the normal distribution, $\tau$ and $\sigma^{2}$ variance components. Random effects were assumed to be mutually independent and independent of errors. All models were fitted with the lme4 package in the $\mathrm{R}$ statistical software (Bates et al., 2015). Predictions used to calculate the MSPE, in each fold of the 10-fold cross validation, were computed only with the fixed regression coefficients, that is,

$$
\hat{\mathbf{y}}_{\mathrm{f}}=\mathbf{X}_{\mathrm{f}} \hat{\boldsymbol{\beta}}_{-\mathrm{f}},
$$

where $\hat{\mathbf{y}}_{\mathbf{f}}$ is a vector of predictions in the fth fold, $\mathbf{X}_{\mathbf{f}}$ is corresponding matrix of independent variables in the $f$ th fold and $\hat{\boldsymbol{\beta}}_{-\mathbf{f}}$ is the vector of regression coefficients estimated with a data set without the fth fold. 
Table 3. Average wind speed, air temperature, and emission rates $( \pm \mathrm{SD})$ from 6 lagoons located in south-central Idaho ${ }^{1}$

\begin{tabular}{lccccc}
\hline Dairy & $\begin{array}{c}\text { Wind speed } \\
(\mathrm{m} / \mathrm{s})\end{array}$ & $\begin{array}{c}\text { Air temperature } \\
\left({ }^{\circ} \mathrm{C}\right)\end{array}$ & $\begin{array}{c}\text { Number of 15-min } \\
\text { data points }{ }^{1}\end{array}$ & $\begin{array}{c}\text { Average } \mathrm{CH}_{4} \text { emissions } \\
(\mathrm{kg} / \text { ha per day })\end{array}$ & $\begin{array}{c}\text { Average } \mathrm{CH}_{4} \text { emissions } \\
(\mathrm{kg} / \mathrm{d})\end{array}$ \\
\hline D1 & $4.3 \pm 2.3$ & $7.9 \pm 13.9$ & 346 & $36 \pm 44$ & $96 \pm 118$ \\
D2 & $5.3 \pm 1.4$ & $14.2 \pm 7.1$ & 575 & $109 \pm 31$ & $517 \pm 146$ \\
D3 & $4.0 \pm 1.8$ & $18.3 \pm 7.4$ & 1,060 & $30 \pm 13$ & $66 \pm 28$ \\
D4 & $4.3 \pm 2.4$ & $16.0 \pm 6.0$ & 1,342 & $68 \pm 62$ & $160 \pm 83$ \\
D5 & $4.3 \pm 1.5$ & $15.7 \pm 7.9$ & 4,382 & $103 \pm 51$ & $24 \pm 7$ \\
D6 & $3.6 \pm 2.0$ & $14.5 \pm 6.9$ & 7,219 & $22 \pm 11$ \\
\hline
\end{tabular}

${ }^{1}$ The number of valid 15-min emissions values used to calculate the average emission rate for each lagoon.

\section{RESULTS AND DISCUSSION}

\section{Average Lagoon Emissions and Temporal Variation in Emissions}

The 6 lagoons ranged in size from 1,300 to 47,398 $\mathrm{m}^{2}$, with depths ranging from 0.3 to $2.7 \mathrm{~m}$ (Table 2). The average wind speed ranged from 3.6 to $5.3 \mathrm{~m} / \mathrm{s}$, whereas the overall range in wind speed at the dairies was from 1.4 to $10.9 \mathrm{~m} / \mathrm{s}$ (Table 3). Average ambient air temperatures ranged from 7.9 to $18.3^{\circ} \mathrm{C}$, with an overall range of -1.4 to $31.5^{\circ} \mathrm{C}$. The lagoons had a fairly wide range of physicochemical characteristics expected to drive $\mathrm{CH}_{4}$ emissions, which are presented in Table 4. Average COD, TS, and VS ranged from 1,456 to $11,171,3,400$ to 11,892 , and 1,581 to 6,224 $\mathrm{mg} / \mathrm{L}$, respectively. Average $\mathrm{pH}$ ranged from 7.7 to 8.3, whereas average lagoon temperatures ranged from 15 to $17^{\circ} \mathrm{C}$. None of the lagoons had crust formation during any time of the year, whereas settling basins typically had a crust over the surface.

Figures 1 and 2 present the $\mathrm{CH}_{4}$ emissions and ambient air temperature over time for each lagoon. In general, emissions from lagoons D1 to D4 had greater emissions during summer months when temperatures were greater. This overall trend has been documented in the literature (Borhan et al., 2011b; Minato et al., 2013; Baldé et al., 2016); however, there were time periods, particularly at D5 and D6, when we saw large emissions spikes at times of the year when temperatures were cooler (early spring and late fall to winter). At D5, we saw spikes at or around d 118, 305, and 354. On d 118, we noted a very strong wind event with an average wind speed of $8.3 \mathrm{~m} / \mathrm{s}$; these high winds tend to agitate the lagoons similar to a pumping or rainfall event and, therefore, could cause an enhanced release of $\mathrm{CH}_{4}$. We also saw this same effect on D4 at d 94, when a spike in emissions was noted on a day with a very high wind event $(11.1 \mathrm{~m} / \mathrm{s})$. Around d 305 at D5, the lagoon was being pumped out, which not only causes agitation of the lagoon waters but also exposes the sludge at the bottom of the lagoon that could enhance transfer of $\mathrm{CH}_{4}$ to the atmosphere. Days 352 to 354 at D5 had very cold temperatures, and the surface of the lagoon was freezing and thawing; we suspect that this freeze/ thaw action also enhanced the release of built up $\mathrm{CH}_{4}$ (trapped under the ice sheets) to the atmosphere when the surface would thaw.

At D6, we noted spikes in emissions during the spring peaking on d 104 as well as spikes in the fall and winter centered on d 304 and 345. In the spring at D6, several factors that, when combined, likely caused high emission rates. We observed a large number of windy days between d 77 and 105, with several days of wind speeds that were above $5 \mathrm{~m} / \mathrm{s}$. In addition, some rain fell during this time period, which would cause perturbation of the lagoon surface. In addition, during this time period we found a $60 \%$ increase in COD (compared with previous sampling date) with a concomitant $56 \%$ decrease in DO (Figure 3). These changes in chemical characteristics of the lagoon suggest that not only was there greater substrate present, but there were greater reducing conditions as well, which combined would enhance

Table 4. Average concentrations $( \pm \mathrm{SD})$ of lagoon characteristics measured over time at 6 dairies monitored for methane in southern Idaho

\begin{tabular}{lccccc}
\hline Dairy & COD $(\mathrm{mg} / \mathrm{L})$ & TS $(\mathrm{mg} / \mathrm{L})$ & VS $(\mathrm{mg} / \mathrm{L})$ & $\mathrm{pH}$ & Temp $\left({ }^{\circ} \mathrm{C}\right)$ \\
\hline D1 & $3,868 \pm 745$ & $5,410 \pm 529$ & $2,648 \pm 299$ & $7.7 \pm 0.3$ & $16 \pm 2$ \\
D2 & $6,057 \pm 1,111$ & $8,941 \pm 1,063$ & $4,419 \pm 522$ & $7.9 \pm 0.1$ & $16 \pm 2$ \\
D3 & $1,456 \pm 411$ & $3,400 \pm 429$ & $1,581 \pm 468$ & $8.2 \pm 0.2$ & $15 \pm 5$ \\
D4 & $11,171 \pm 1,124$ & $11,892 \pm 1,223$ & $6,224 \pm 767$ & $7.9 \pm 0.2$ & $17 \pm 3$ \\
D5 & $4,711 \pm 1,353$ & $8,756 \pm 2,843$ & $3,349 \pm 720$ & $8.3 \pm 0.3$ & $16 \pm 4$ \\
D6 & $5,758 \pm 910$ & $9,855 \pm 1,964$ & $4,050 \pm 680$ & $8.2 \pm 0.4$ & $15 \pm 4$ \\
\hline
\end{tabular}

${ }^{1} \mathrm{COD}=$ chemical oxygen demand; VS = volatile solids; Temp = lagoon water temperature. 


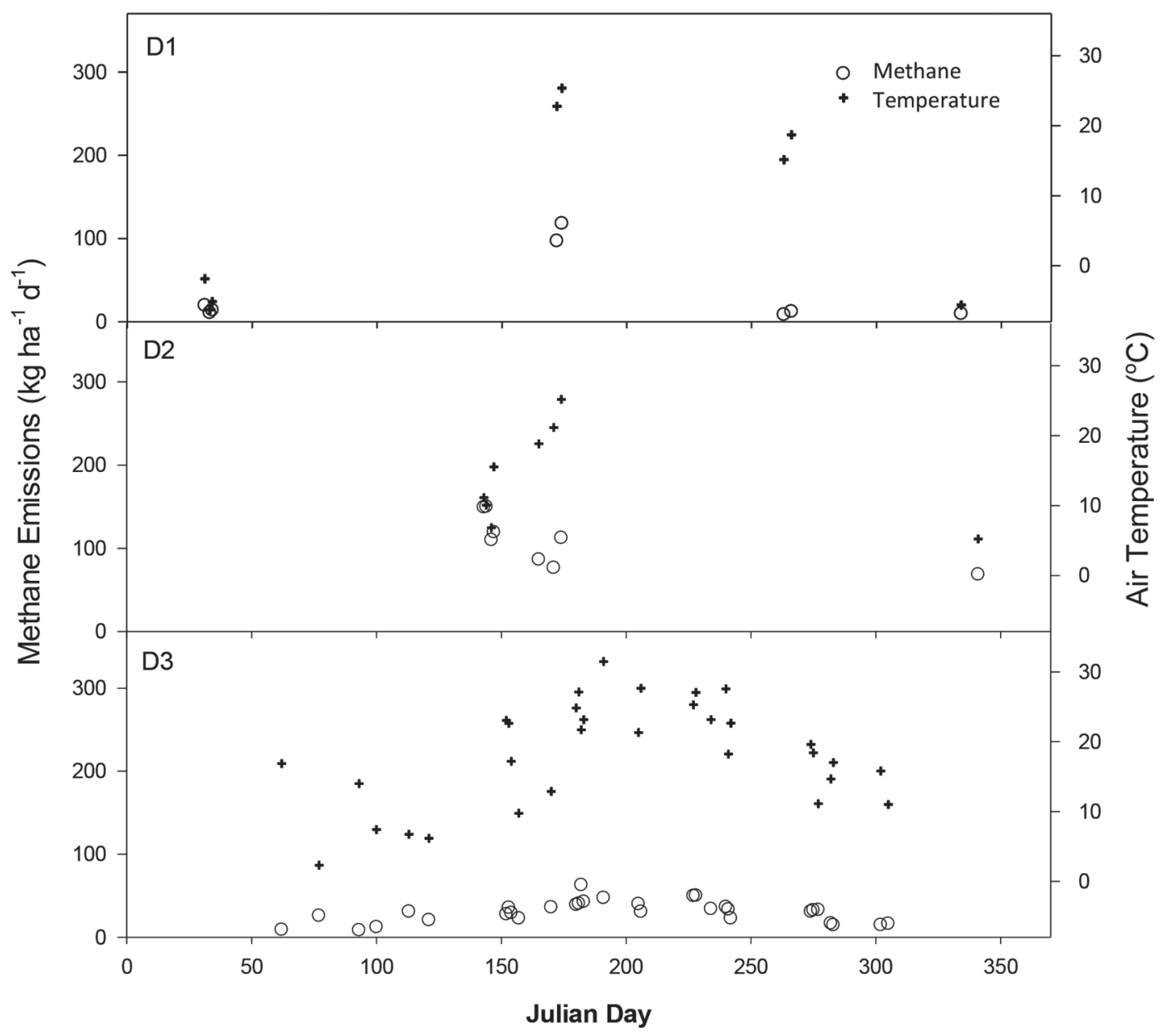

Figure 1. Measured on-farm methane emissions and air temperature over time from farms D1 to D3 located in south-central Idaho.

$\mathrm{CH}_{4}$ production. Later in the year, the D6 lagoon was being pumped out around d 304 and 345 along with some freezing and thawing of the lagoon surface around d 345. We suspect that these factors are responsible for the spikes that were seen in emissions during these time periods.

Methane fluxes were strongly influenced by shortterm events, similar to those which have been noted previously in the literature (Husted, 1994; Kaharabata and Schuepp, 1998; VanderZaag et al., 2009). VanderZaag et al. (2010b) reported that $\mathrm{CH}_{4}$ flux trends from dairy slurry in tanks consisted of 2 main components: baseline fluxes due to diffusion and intermittent bursts due to bubble flux (ebullition). Therefore, events that either promote or interfere with these processes are likely to affect emission rates. Agitation of slurry tanks, with and without crusts or covers, has been shown to generate spikes in $\mathrm{CH}_{4}$ emissions, caused by the enhanced diffusion of $\mathrm{CH}_{4}$ and the release of trapped $\mathrm{CH}_{4}$ bubbles (Kaharabata and Schuepp, 1998; VanderZaag et al., 2014; Baldé et al., 2016). Rainfall events have also been shown to generate spikes in $\mathrm{CH}_{4}$ emissions due to surface disturbances (VanderZaag et al., 2010a; Minato et al., 2013; Baldé et al., 2016). In fact, Kaharabata and Schuepp (1998) reported that two-thirds of rainy days showed concentration increases by factors of 1.2 to 4 during the sampling interval compared with the surrounding days. Those authors surmised that the mechanical agitation of the slurry surface increased the exchange of $\mathrm{CH}_{4}$ through increased liquid surface area via the creation of ripples and through the augmentation of the ebullition process. Ice formation occurring at the surface of a lagoon or slurry tank can inhibit loss of $\mathrm{CH}_{4}$ via diffusion or ebullition, and upon thawing this trapped gas can be released, causing increased trends in emissions (VanderZaag et al., 2010b, 2011). VanderZaag et al. (2011) reported that spring thaw of a dairy slurry tank coincided with the highest $\mathrm{CH}_{4}$ flux measured during the entire study. A second spring thaw coincided with the second highest $\mathrm{CH}_{4}$ flux rate, sug- 


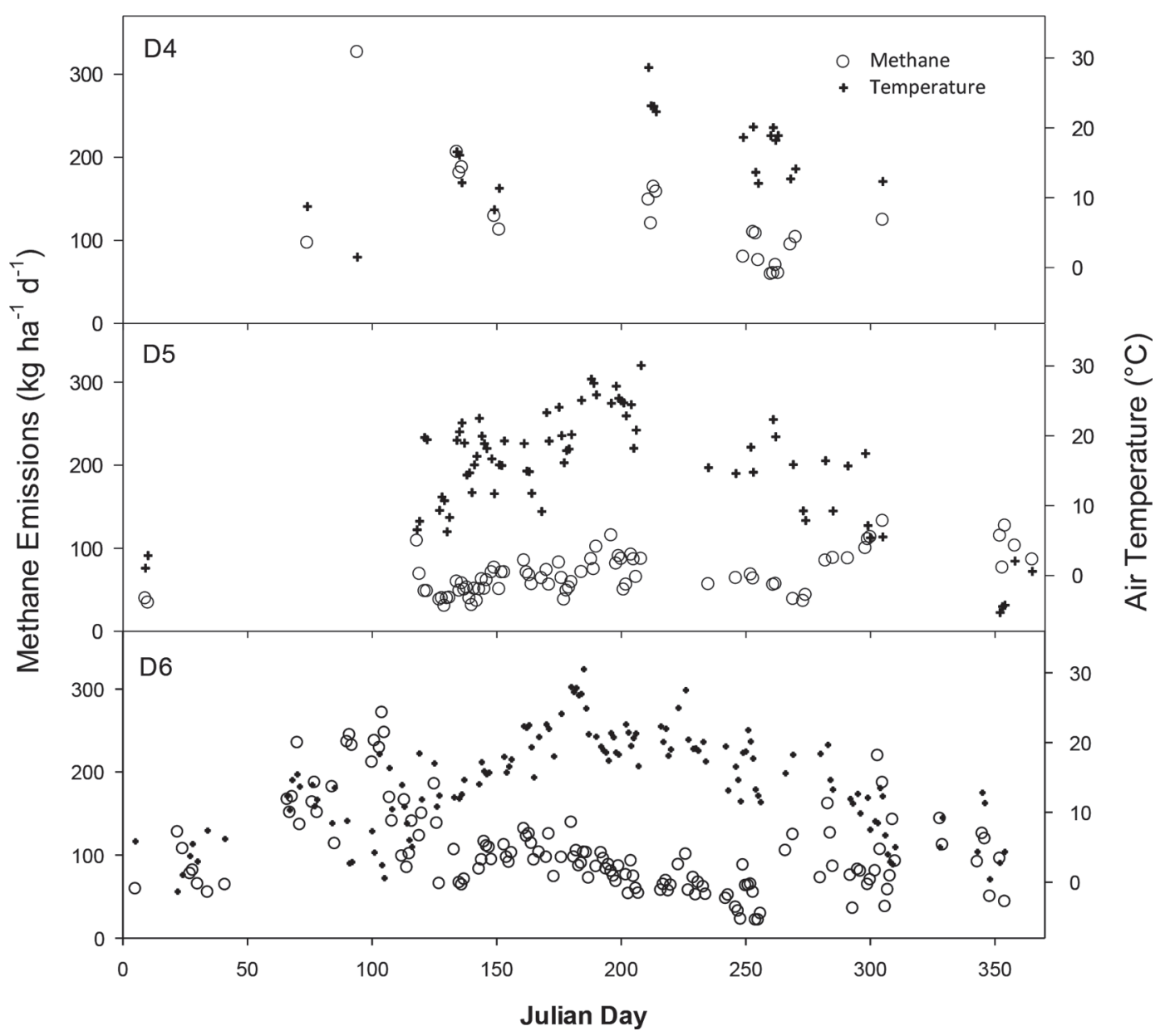

Figure 2. Measured on-farm methane emissions and air temperature over time from farms D4 to D6 located in south-central Idaho.

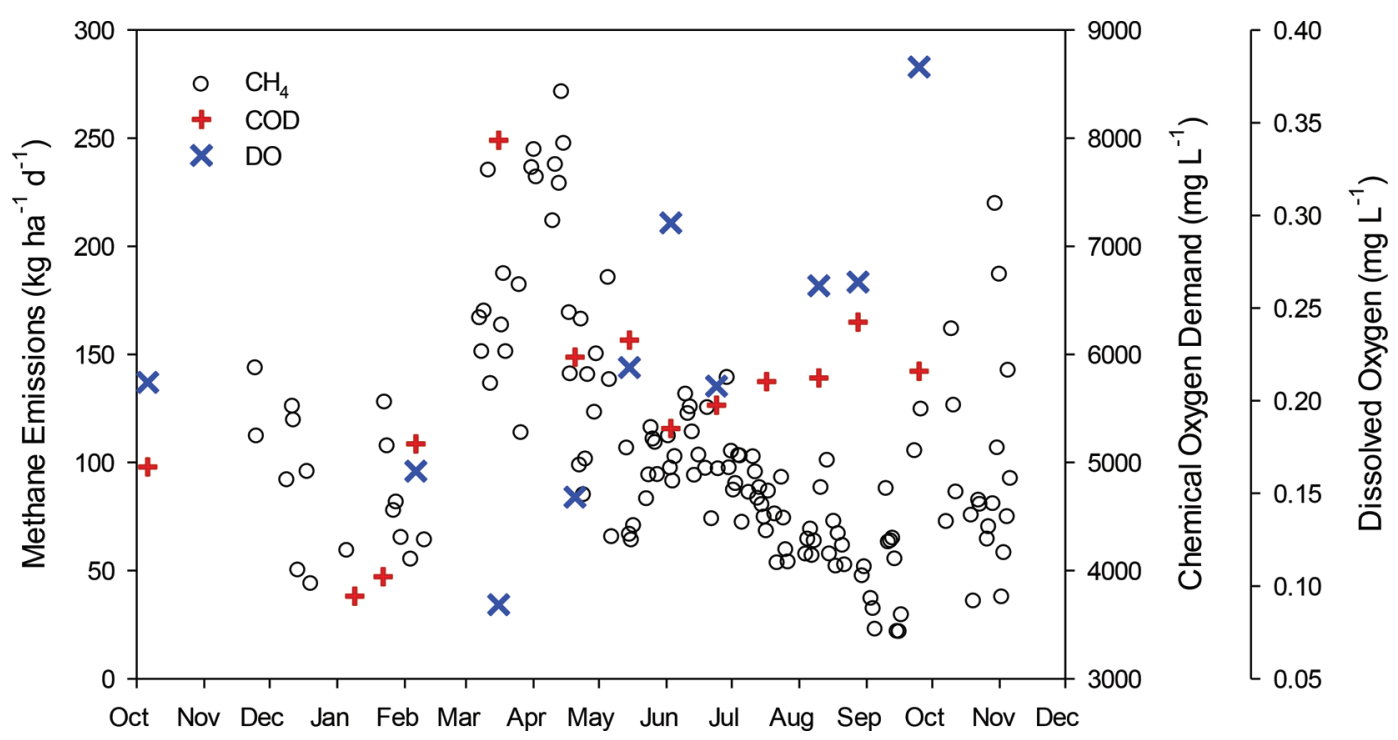

Figure 3. Methane emissions and lagoon characteristics (D6) measured over time at a dairy lagoon in south-central Idaho. Color version available online. 
gesting that the quantity of dissolved $\mathrm{CH}_{4}$ and bubbles were decreasing with each thaw. Following these flux events, $\mathrm{CH}_{4}$ emissions tended to decrease significantly until more $\mathrm{CH}_{4}$ built up in the system. Grant et al. (2015) reported a positive relationship between wind speed and $\mathrm{CH}_{4}$ flux at dairy lagoons during certain times of the year. It is thought that wind shear at the surface promotes the emission of $\mathrm{CH}_{4}$ through turbulent diffusion of the gases released from solution at the surface (Ro and Hunt, 2006).

We binned the hourly data together by season; an example is seen in Figure 4 for D6, to look for diel patterns in emissions. The daily variability in emissions was larger than diel trends in emissions. This is contrary to the diel trend found by Todd et al. (2011), who reported a spike in $\mathrm{CH}_{4}$ flux early in the morning each day, corresponding to the formation and dissipation of a bubble scum on the surface of the lagoon. However, the Todd et al. (2011) study was only conducted for $7 \mathrm{~d}$ in the summer and, therefore, less daily variation was captured in that study compared with the present study. Baldé et al. (2016) also reported the same increases in $\mathrm{CH}_{4}$ flux from a dairy slurry tank in the early morning during July and August. Although, in the present study, the variability in emissions each hour is quite large, in the spring and summer there appeared to be a peak in emissions in the early morning at D2 to D6 (not all data shown); in some cases this was followed by a second peak later in the day as temperatures increased.

As the variation in emissions over a 24 -h period appeared to be less than the daily variation in emissions, annual emissions were calculated by averaging all of the available data from each lagoon. The number of 15-min data points that went into each average ranged from 346 to 7,219 (Table 3). When compared on an area basis, average $\mathrm{CH}_{4}$ emissions ranged from 30 to $126 \mathrm{~kg} / \mathrm{ha}$ per day. The greatest emissions were from D4, which was expected, as this lagoon system received all of the manure solids from the lactating herd and had the highest COD, TS, and VS concentrations. The lowest average emissions were from D3, which received very few inputs into the system as the dairy switched from a lactating to a heifer operation. However, even with little added manure, this lagoon still produced significant quantities of $\mathrm{CH}_{4}$, which was similar to one of the active dairies. The areal emissions in our study fall within the range reported in the literature (Table 1). On a daily basis, $\mathrm{CH}_{4}$ production ranged from 22 to $517 \mathrm{~kg} / \mathrm{d}$, with the greatest emissions from D2. As the lagoons monitored did not capture emissions from the entire liquid storage, in many cases it is not possible to make meaningful comparisons of daily emissions between the different manure storage systems.

\section{Correlation of $\mathrm{CH}_{4}$ with Meteorological Conditions and Lagoon Characteristics}

Linear regression revealed very weak trends between $\mathrm{CH}_{4}$ emissions and meteorological conditions (Figure 5). We observed little relationship between $\mathrm{CH}_{4}$ emissions and ambient air temperature $\left(\mathrm{R}^{2}=0.02 ; P=\right.$ 0.02). This demonstrates that, although temperature certainly drives the chemical and biological activity that generates $\mathrm{CH}_{4}$, other conditions can have a large effect on these emissions, such as agitation of the surface, pumping, and freezing and thawing. We found a strong relationship between wind speed and $\mathrm{CH}_{4}$ emissions $\left(\mathrm{R}^{2}\right.$ $=0.13, P<0.001)$. The effect of high wind events on mixing of the lagoons and agitation of lagoon surfaces seemed to drive high flux events in addition to enhancing $\mathrm{CH}_{4}$ transport. No significant relationship was ob-

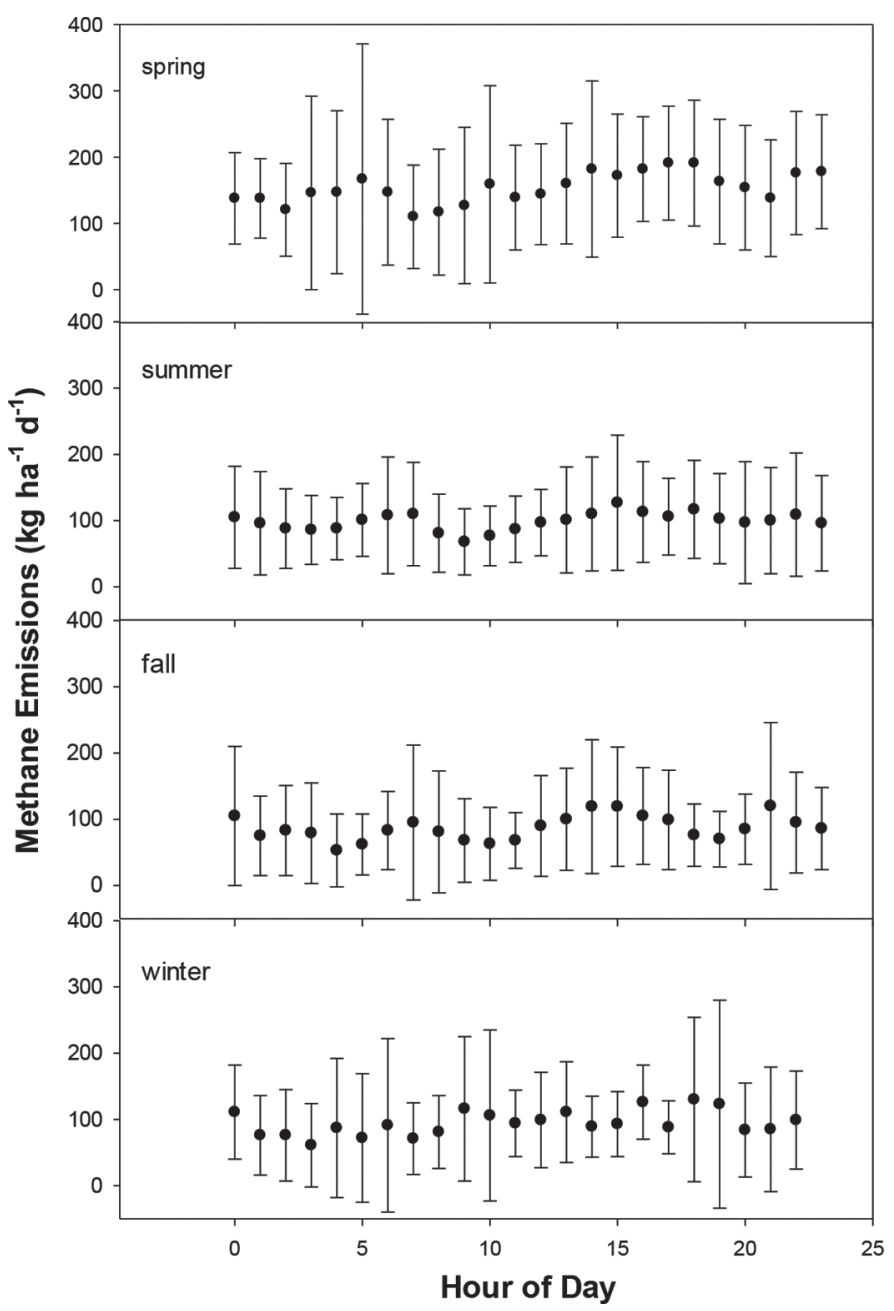

Figure 4. Hourly emissions of methane binned over each season (spring, summer, fall, winter) at a dairy lagoon (D6) in south-central Idaho. Error bars represent the SD of the mean hourly average over the season. 


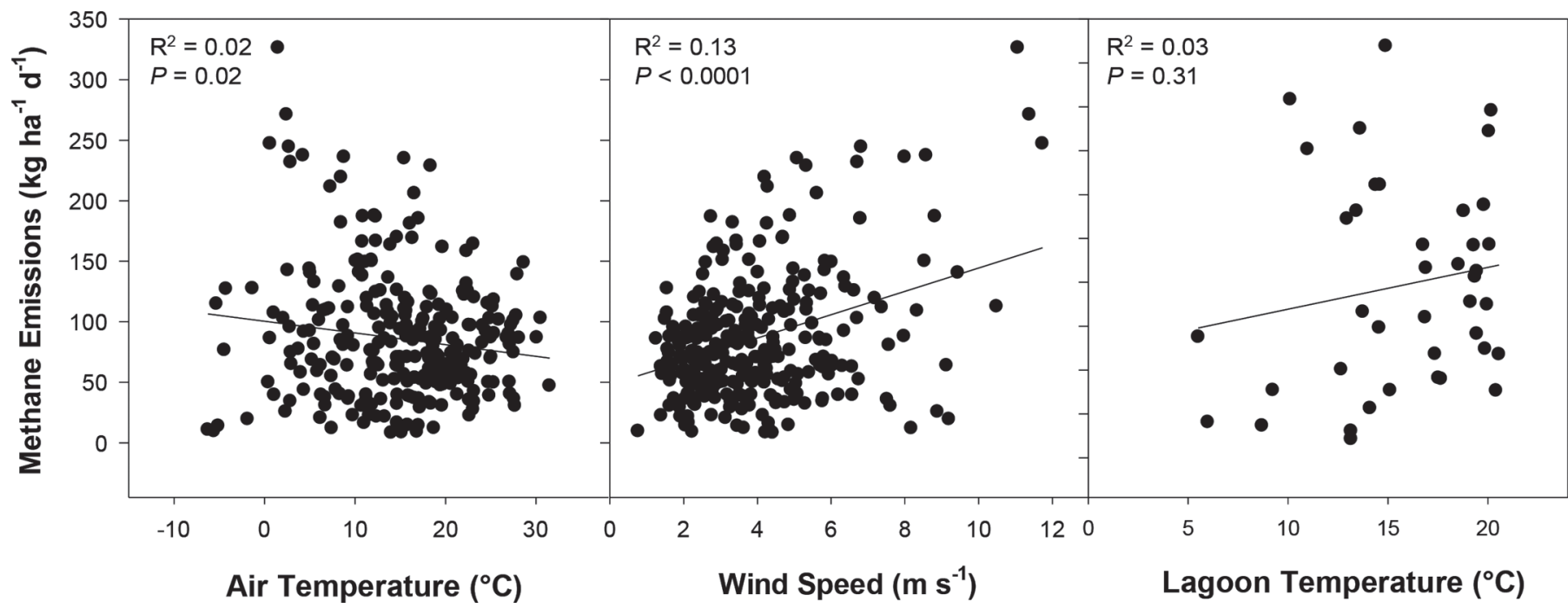

Figure 5. Linear regression of average daily emissions measured at dairy lagoons in south-central Idaho with meteorological conditions.

served between lagoon temperature and emissions $\left(\mathrm{R}^{2}\right.$ $=0.03, P=0.31$. Safley and Westerman (1992) also found weak relationships between $\mathrm{CH}_{4}$ generation and temperature in a dairy lagoon, and in fact reported a negative relationship between sludge temperature and $\mathrm{CH}_{4}$ concentration.

Because of large range in the physicochemical properties of the lagoons in our study, the effects of temperature were likely confounded by other lagoon characteristics as well as other events that affected $\mathrm{CH}_{4}$ emissions. The relationships between lagoon physicochemical properties and $\mathrm{CH}_{4}$ emissions were much stronger than those with meteorological conditions (Figure 6). Methane emissions were positively related to TS, COD, and VS, with $\mathrm{R}^{2}$ ranging from 0.47 to $0.52(P<0.0001)$ and COD having the highest $R^{2}$ value. This suggests that, overall, lagoon properties may be a larger factor in determining emissions than temperature.

One additional factor that could be affecting emissions on these dairies is the presence of purple sulfur bacteria (PSB) and other microorganisms in the lagoons. All but D2 and D4 had a strong pink coloration of the lagoon, indicating the presence of PSB, which is common for lagoons in this region (Dungan and Leytem, 2015). The proliferation of the PSB tend to increase with temperature; therefore, the ponds tend to

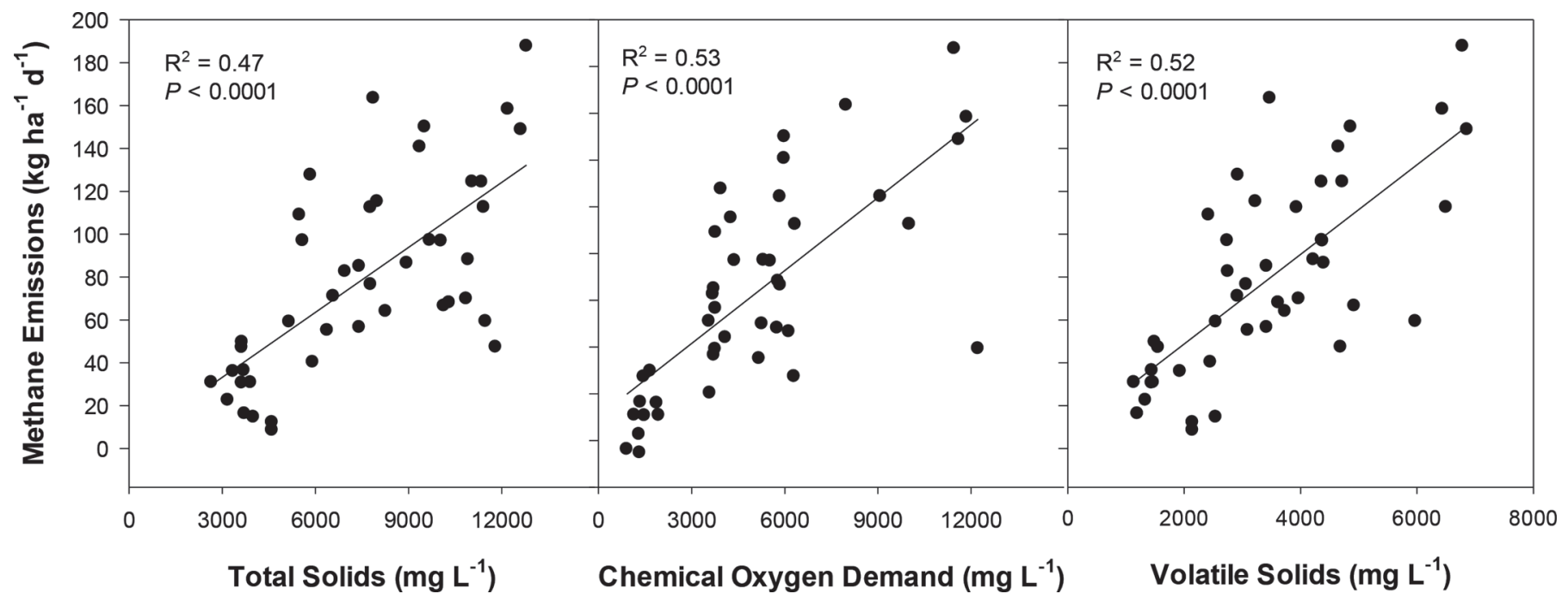

Figure 6. Linear regression of average daily emissions measured at dairy lagoons in south-central Idaho with lagoon physicochemical characteristics. 
not express signs of the presence of PSB in early spring and winter but will become a pink/purple color starting in late April to early May and reach peak color by July. Holm and Vennes (1970) also found that PSB in sewage treatment lagoons reached maximal concentrations in the warmest part of the summer, with laboratory studies indicating that the bacteria grew over the temperature range of 16 to $30^{\circ} \mathrm{C}$, with optimal temperature at 25 to $30^{\circ} \mathrm{C}$. As $\mathrm{CH}_{4}$ is a good electron donor, some sulfate-reducing bacteria may play a role in the anaerobic oxidation of $\mathrm{CH}_{4}$ (Barton and Fauque, 2009) via the following reaction:

$$
\mathrm{CH}_{4}+\mathrm{SO}_{4}{ }^{2-} \rightarrow \mathrm{HCO}_{3}^{-}+\mathrm{HS}^{-}+\mathrm{H}_{2} \mathrm{O} .
$$

Barton and Fauque (2009) also noted that the biological oxygen demand in a wastewater lagoon decreased with PSB growth. It is possible that, as lagoon temperature increases in the summer and PSB populations increase, they oxidize some $\mathrm{CH}_{4}$ in the lagoons; therefore, the peak emissions expected during high temperatures in the summer could be counteracted by the utilization of $\mathrm{CH}_{4}$ by the PSB population. The presence of purple nonsulfur bacteria has also been detected in swine lagoons (Okubo et al., 2006); purple nonsulfur bacteria also have the capacity to reduce $\mathrm{CH}_{4}$ emissions (Nunkaew et al., 2015). More research would need to be done to test this hypothesis.

\section{Predicting $\mathrm{CH}_{4}$ Based on Meteorological Conditions and Lagoon Properties}

As it may be difficult to determine actual VS loading rates at any given lagoon and several meteorological and management factors appear to be driving emissions, we wanted to determine if there was a way to estimate emissions from these lagoons using simple characteristics that would either be publically available (meteorological) or could be easily measured. Whereas we fully understand that the lagoon samples themselves do not measure the total amount of COD, TS, and VS in the lagoon system, we wanted to test if they could be used as a proxy for estimating the $\mathrm{CH}_{4}$ emissions from the lagoons. Therefore, we tested models that included ambient air temperature, wind speed, lagoon specific conductivity, VS, TS, COD, and $\mathrm{pH}$ to determine if we could estimate lagoon $\mathrm{CH}_{4}$ emissions.

The selected models (i.e., the models with smallest AIC in each 1 of the 4 pools of independent variables) are presented in Table 5. The square root of the MSPE for each model, determined through a 10-fold cross validation, are also presented in Table 5 . The model with the smallest prediction error (Model 2) included
VS, wind speed, mean air temperature, and $\mathrm{pH}$ as independent variables. The model with the second smallest prediction error (Model 3) included TS instead of VS as an independent variable. A third model (Model 4) with similar prediction error had COD, wind speed, mean air temperature, and $\mathrm{pH}$ as independent variables (Table 5). Model 4 had the smallest AIC, although the AIC of the 3 previously described models were very similar (Table 5). These results suggest that lagoon TS, VS, COD, and $\mathrm{pH}$, as well as mean air temperature and wind speed, may be useful for estimating lagoon $\mathrm{CH}_{4}$ emissions.

The prediction errors were substantially large when compared with the mean of the $\mathrm{CH}_{4}$ emissions. In particular, the square root of the MSPE ranged from 48.7 to $58.4 \%$ of the observed $\mathrm{CH}_{4}$ emission mean. Diagnostic plots (Figure A1) suggested considerable variation in the predictions, especially in predictions of high $\mathrm{CH}_{4}$ emission rates. In particular, analysis of residuals suggested large variation in predictions and possible heterogeneity in the data (i.e., a variance that increases with the predicted values). Therefore, the same models described in the previous section were fitted with $\mathrm{CH}_{4}$ emissions transformed with a natural logarithm operation (Kutner at al., 2004). In essence, the dependent variable is now $y^{\prime}=\log (y)$, and the model selection, fitting, and cross-validation procedures were reconducted with $\mathrm{CH}_{4}$ in the natural logarithmic scale. The fitted models, with associated AIC and MSPE are presented in Table 5. The selection of variables was unchanged and the ranking of models, based on both AIC and prediction error, were also the same as when using $\mathrm{CH}_{4}$ in the original scale (i.e., in $\mathrm{kg} / \mathrm{ha}$ per day). Model 2 had the smallest prediction error and had lagoon VS, $\mathrm{pH}$, mean air temperature, and wind speed as independent variables. The prediction error, obtained through cross validation, ranged from 9.66 to $13.1 \%$ of the mean of the calculated natural logarithm of $\mathrm{CH}_{4}$ emissions. Analysis of residuals suggested a better ability of the model in describing the data when compared with the models fitted in the original scale, especially for predictions of large $\mathrm{CH}_{4}$ emissions (Figure A2). The predicted versus on-farm measurements using model 2 (Table 5) are presented in Figure 7. Even given the large range in weather conditions and lagoon characteristics, the model did a good job of predicting emissions across farms; however, these equations may only be useful for farms in this region.

\section{$\mathrm{CH}_{4}$ Emissions from the Settling Basins}

The emissions from the settling basins on 2 dairies (D3, D6) were also estimated to determine the con- 


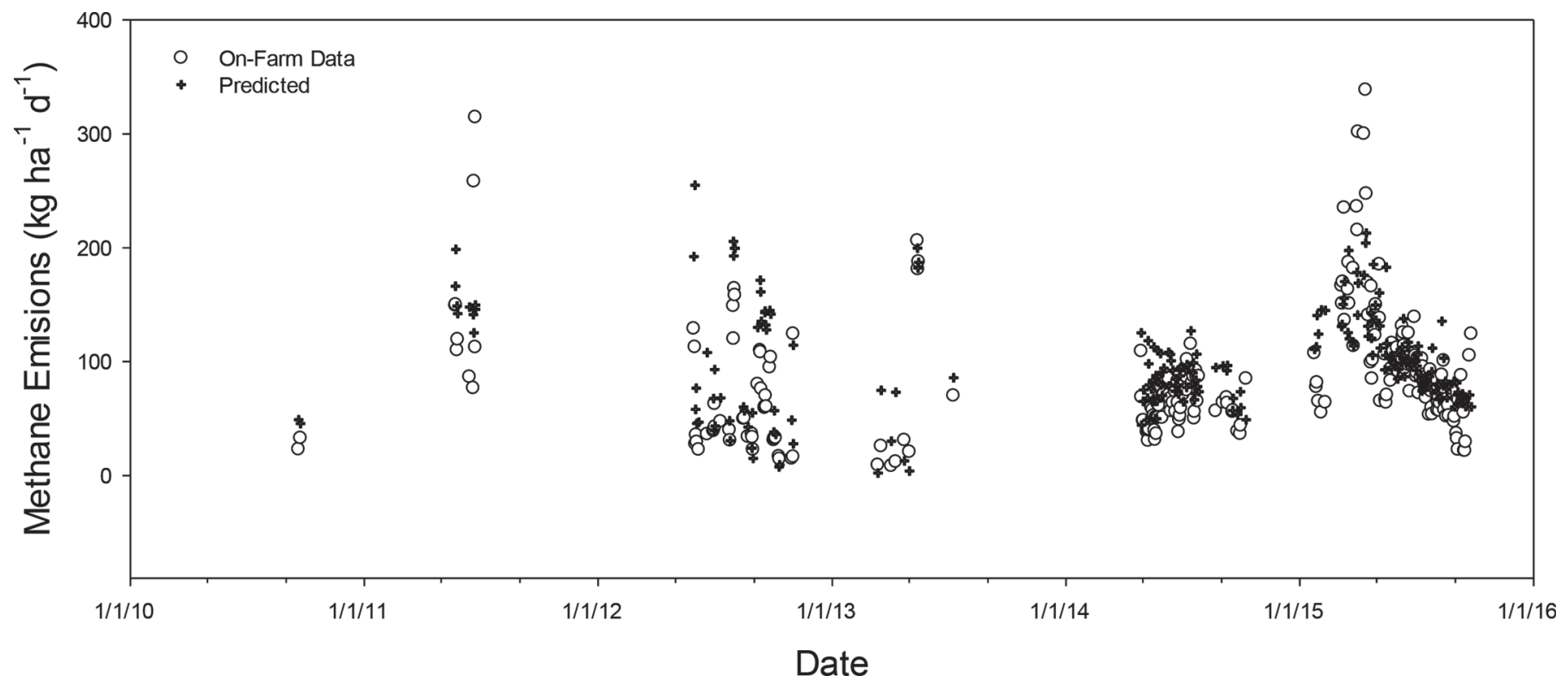

Figure 7. On-farm methane emissions for all lagoons monitored in the study compared with estimated emissions predicted using model 2 (Table 5).

tribution of these basins to the overall lagoon system emissions. These dairies had either one (D6) or a series of settling basins (D3) in addition to a primary lagoon, which allowed us to examine the relative contribution of the settling basins to the overall liquid-storage system (Figure 8). We did not expect to observe high levels of $\mathrm{CH}_{4}$ emissions from the settling basins, as they are smaller than the lagoons and tend to be covered by a thick crust, which has been shown to inhibit $\mathrm{CH}_{4}$ emissions (Husted, 1994; Sommer et al., 2000). At D3 the proportion of total $\mathrm{CH}_{4}$ emissions originating from the settling basin ranged from 0.34 to 0.71 with an average of 0.52 , whereas at $\mathrm{D} 6$ the proportion ranged from 0.13 to 0.65 with an average of 0.44 . The $\mathrm{CH}_{4}$ emissions from the settling basins seemed to be more affected by air temperature than the lagoons, and we noted a strong relationship between fraction of $\mathrm{CH}_{4}$ generated from the settling basins versus ambient air temperature $\left(R^{2}=0.40 ;\right.$ Figure A3). This sensitivity to temperature is likely due to the smaller size of the basins, which

Table 5. Methane prediction models and associated Akaike information criteria (AIC) and square root of the mean square prediction error (RMSPE) obtained through cross validation ${ }^{1}$

\begin{tabular}{|c|c|c|c|c|}
\hline Model $^{2}$ & Prediction equation $^{3}$ & $\mathrm{AIC}$ & $\begin{array}{c}\mathrm{RMSPE}^{4} \\
\text { (kg/ha per day) }\end{array}$ & $\begin{array}{l}\mathrm{RMSPE}^{4} \\
\text { (\% of mean) }\end{array}$ \\
\hline \multicolumn{5}{|c|}{ Original scale } \\
\hline 1 & $\mathrm{CH}_{4}=479.3+14.5 \times$ Wind $+1.78 \times \mathrm{Tm}-57.2 \times \mathrm{pH}$ & 2,361 & 50.7 & 58.4 \\
\hline 3 & $\mathrm{CH}_{4}=593.4+0.006 \times \mathrm{TS}+14.6 \times$ Wind $+1.48 \times \mathrm{Tm}-77.2 \times \mathrm{pH}$ & 2,360 & 43.5 & 50.1 \\
\hline 4 & $\mathrm{CH}_{4}=365.5+0.014 \times \mathrm{COD}+13.8 \times$ Wind $+1.51 \times \mathrm{Tm}-51.7 \times \mathrm{pH}$ & 2,349 & 45.3 & 52.2 \\
\hline \multicolumn{5}{|c|}{ T } \\
\hline 3 & $\begin{array}{l}\log \left(\mathrm{CH}_{4}\right)=10.8+0.0001 \times \mathrm{TS}+0.139 \times \mathrm{Wind}+0.031 \times \mathrm{Tm}-1.031 \times \\
\mathrm{pH}\end{array}$ & 203.9 & 0.42 & 9.74 \\
\hline 4 & $\begin{array}{l}\log \left(\mathrm{CH}_{4}\right)=8.51+0.0001 \times \mathrm{COD}+0.134 \times \text { Wind }+0.033 \times \mathrm{Tm}-0.719 \\
\times \mathrm{pH}\end{array}$ & 200.8 & 0.46 & 10.7 \\
\hline
\end{tabular}

${ }^{1}$ Emissions are either expressed in $\mathrm{kg} /$ ha per day or in a natural logarithm scale.

${ }^{2}$ Models 1, 2, 3, and 4 are the models with smallest AIC in pools of independent variables 1, 2, 3, and 4 .

${ }^{3}$ Wind is the wind speed $(\mathrm{m} / \mathrm{s})$, Tm is the mean air temperature $\left({ }^{\circ} \mathrm{C}\right)$, VS is the volatile solids $(\mathrm{mg} / \mathrm{L})$, TS is the total solids $(\mathrm{mg} / \mathrm{L})$, COD is the chemical oxygen demand $(\mathrm{mg} / \mathrm{L})$, TKN is the total Kjeldahl nitrogen $(\mathrm{mg} / \mathrm{L})$, and the TAN is the total ammonia nitrogen $(\mathrm{mg} / \mathrm{L})$.

${ }^{4}$ With a 10 -fold cross-validation and using only fixed regression coefficients. 


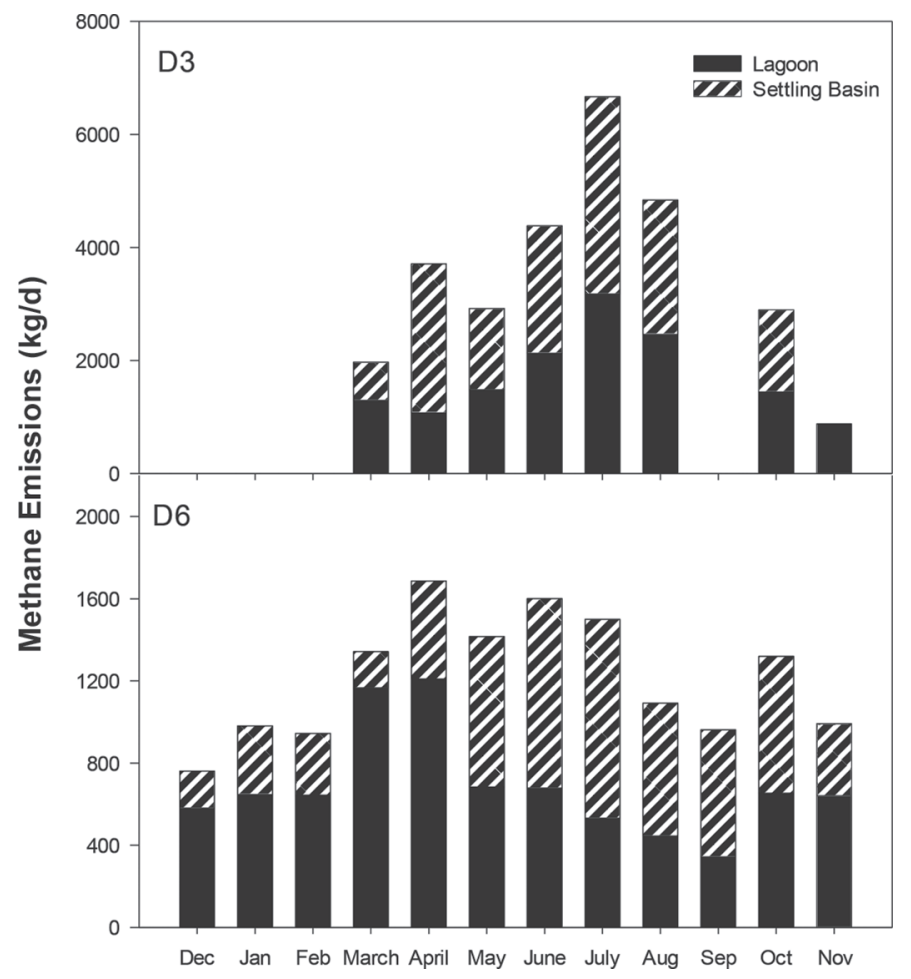

Figure 8. Emissions of methane from the primary lagoons and settling basins of 2 dairies (D3, D6) in south-central Idaho.

could inhibit their ability to buffer against temperature changes as well as the crusting. As temperatures increase and the crusts dry out, the crust permeability likely increased along with crust porosity, which could reduce the effectiveness of the crusts to inhibit $\mathrm{CH}_{4}$ emissions during warmer temperatures (Husted, 1994). Borhan et al. (2011b) also found that the settling basin of a dairy was producing nearly twice as much $\mathrm{CH}_{4}$ as the primary lagoon in the summer, yet in the winter the primary lagoon was producing 6.5 times as much $\mathrm{CH}_{4}$ as the settling basin.

\section{On-Farm Versus Predicted Emissions}

We estimated the monthly and annual emissions from the lagoon system at D6 using the USEPA inventory methodology to see how closely they compared (Figure 9). The cumulative emissions estimated with the USEPA inventory method were $48 \%$ lower than the actual measured on-farm emissions (combining the lagoon and settling basin emissions). Baldé et al. (2016) reported that the USEPA estimate for a dairy slurry tank was 48 to $59 \%$ lower than measured emissions. As seen in Figure 9, the inventory model appears to be highly dependent on temperature (Figure 9b), with a large peak in July and low emissions in late fall through spring. The emissions from the settling basin tended to follow this trend with temperature, although the model underestimated $\mathrm{CH}_{4}$ emissions in late fall. This trend of higher fall emissions has also been reported by VanderZaag et al. (2009). In contrast, the emissions from the primary lagoon were much higher throughout the late fall through spring, with peak emissions in the spring. This led to total $\mathrm{CH}_{4}$ emissions (lagoon + settling basins) that were greater than estimated with the USEPA model for all but 2 mo (July and August).

Several factors could account for these large discrepancies between estimated and measured emissions. The inventory method assumes a complete cleanout of the lagoon systems in October; however, the water in lagoon D6 (and all of the lagoons studied) was regularly pumped out in late fall and spring, but the sludge at the bottom was not removed. In addition, the settling basins may be cleaned out very infrequently, with the settling basin at D6 not having been cleaned out during the 2-yr period that we worked at this dairy. Therefore, there is likely unaccounted VS remaining in the system available for breakdown over time as well as serving as a constant inoculum, which maintains high levels of $\mathrm{CH}_{4}$ generation even after the lagoons are pumped out. A lag phase in $\mathrm{CH}_{4}$ emissions of up to $50 \mathrm{~d}$ has been noted in the literature when manure is stored in clean tanks, after which $\mathrm{CH}_{4}$ emissions increase exponentially (VanderZaag et al., 2010a).

The $\mathrm{B}_{\mathrm{o}}$ values used in the USEPA emissions estimates were derived from research on the biological activity of $\mathrm{CH}_{4}$ digesters (Bryant et al., 1976; Morris, 1976; Hashimoto et al., 1981; Hashimoto, 1983), which may not represent the lagoons monitored in our study. The broader microbial community, longer residence times, and lower loading rates of uncovered anaerobic lagoons may lead to higher VS degradation rates than those found in anaerobic digesters (Lory et al., 2010). The $\mathrm{B}_{\mathrm{o}}$ value only estimates the $\mathrm{CH}_{4}$ production based on VS added, it does not estimate the total amount of VS that can be degraded in a digester or lagoon. According to a review of the literature, Lory et al. (2010) surmised that a properly operating uncovered anaerobic lagoon can break down solids to a higher degree than is predicted using anaerobic digester models. Therefore, $\mathrm{B}_{\mathrm{o}}$ may underestimate the potential amount of $\mathrm{CH}_{4}$ generated from these lagoons and thus underestimate overall $\mathrm{CH}_{4}$ emissions.

We estimated the annual $\mathrm{CH}_{4}$ emissions from the lagoon at D6 using the methodology of Lory et al. (2010) to see how closely they compared (Table 6). This method uses a VSDF to estimate the potential VS degradation from uncovered anaerobic dairy lagoons coupled with the amount of $\mathrm{CH}_{4}$ generated from the destruction of these VS $\left(\mathrm{B}^{\prime}\right)$ to estimate an annual $\mathrm{CH}_{4}$ emission 
factor. The value of VSDF (0.57) was calculated as an average of reported literature values, whereas a range of $\mathrm{B}^{\prime}(0.45-0.85)$ was used because of uncertainty in the correct estimate of this parameter. Utilizing this equation, the range in estimated emissions at D6 was 10,495 to $19,824 \mathrm{~kg}$ of $\mathrm{CH}_{4} / \mathrm{yr}$, which encompassed the value measured on the farm $\left(14,594 \mathrm{~kg}\right.$ of $\left.\mathrm{CH}_{4} / \mathrm{yr}\right)$. Using the on-farm measured $\mathrm{CH}_{4}$ emissions, we calculated a value of 0.63 for B'.

As we were only able to make this comparison on 1 dairy lagoon, we used the data of Baldé et al. (2016), who monitored annual emissions from a dairy slurry tank to calculate the annual emissions using the Lory et al. (2010) methodology. In this comparison, we used the reported annual VS loading rate of $294,000 \mathrm{~kg} / \mathrm{yr}$ and the VSDF and $\mathrm{B}^{\prime}$ values stated above. This estimate provided a range in emissions of 49,922 to $94,297 \mathrm{~kg}$ of $\mathrm{CH}_{4} / \mathrm{yr}$, whereas the measured on-farm emissions were
$42,000 \mathrm{~kg}$ of $\mathrm{CH}_{4} / \mathrm{yr}$ (Table 6). The estimates generated from the Lory et al. (2010) methodology were much closer than that estimated using the USEPA methodology $\left(17,000 \mathrm{~kg}\right.$ of $\left.\mathrm{CH}_{4} / \mathrm{yr}\right)$. Baldé et al. (2016) reported emissions from a slurry tank that, due to the frequency of cleanouts, may operate more like a batch reactor than a typical anaerobic lagoon where the sludge is rarely removed from the system. Therefore, we might expect less $\mathrm{CH}_{4}$ produced from these systems than from an anaerobic lagoon system and perhaps perform more like an anaerobic digester. We repeated the calculation above, but used the VSDF factor for anaerobic digesters (0.42) reported by Lory et al. (2010). This provided an estimate of 36,784 to $69,482 \mathrm{~kg}$ of $\mathrm{CH}_{4} / \mathrm{yr}$, encompassing the on-farm measured value. Using this value for VSDF (0.42) we calculated a $\mathrm{B}^{\prime}$ value of 0.51 for this slurry tank. Craggs et al. (2008) also reported a VS removal rate of $59 \%$ from an anaerobic dairy lagoon in

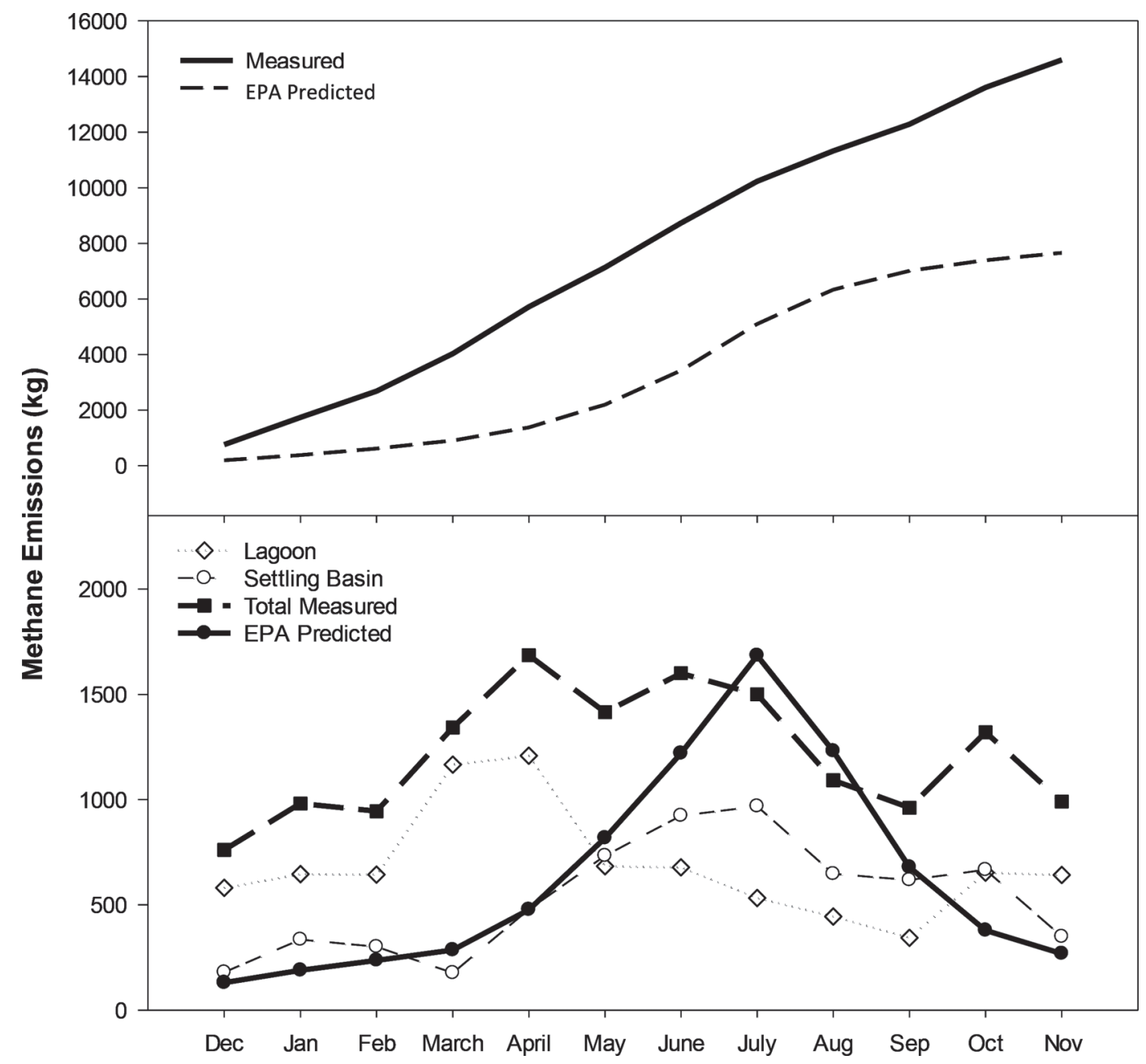

Figure 9. Cumulative on-farm emissions of methane from a dairy lagoon in south-central Idaho (D6) and emissions estimates calculated using the US Environmental Protection Agency (EPA) methodology (USEPA, 2016a) for estimating methane emissions from manure storage. 
Table 6. On-farm and estimated methane $\left(\mathrm{CH}_{4}\right)$ emissions calculated for lagoon D6 and data from Baldé et al. (2016) using the USEPA methodology and the methodology proposed by Lory et al. (2010)

\begin{tabular}{llccc}
\hline Data set & Methodology & VSDF $^{1}$ & $\mathrm{~B}^{\prime 2}$ & $\begin{array}{c}\text { Annual } \mathrm{CH}_{4} \text { emissions } \\
\left.\text { (kg of CH } \mathrm{CH}_{4} / \mathrm{yr}\right)\end{array}$ \\
\hline Present study & On-farm measurement & & & 14,594 \\
& USEPA - monthly & \\
& USEPA - annual & & 8,187 \\
& Lory et al. (2010) & & & 6,776 \\
Baldé et al., 2016 & 0.57 & 0.45 & 10,495 \\
& Lory et al. (2010) & 0.57 & 0.85 & 19,824 \\
& On-farm measurement & & & 42,000 \\
& USEPA - monthly & & & 17,000 \\
& Lory et al. (2010) & 0.57 & 0.45 & 49,922 \\
& Lory et al. (2010) & 0.57 & 0.85 & 94,297 \\
& Lory et al. (2010) & 0.42 & 0.45 & 36,784 \\
& Lory et al. (2010) & 0.42 & 0.85 & 69,482 \\
\hline
\end{tabular}

\footnotetext{
${ }^{1} \mathrm{VSDF}=$ volatile solids destroyed during storage, based on literature value of 0.57 for uncovered anaerobic lagoons and 0.42 for anaerobic digesters.

${ }^{2} \mathrm{~B}^{\prime}=$ conversion of destroyed volatile solids to methane, with values ranging from 0.45 to 0.85 .

${ }^{3}$ Emissions calculated using a monthly time step, with monthly average air temperature accounting for volatile solids added and destroyed each month.

${ }^{4}$ Emissiosn calculated using the annual volatile solids produced and an annual reported methane conversion factor.
}

New Zealand and a biogas production rate of $0.44\left(\mathrm{~m}^{3} /\right.$ $\mathrm{kg}$ of VS removed), which is very similar to those estimated by Lory et al. (2010) and determined with the present data. Although these are only 2 comparisons, it appears that the methodology proposed by Lory et al. (2010) may provide better estimates of $\mathrm{CH}_{4}$ emissions from stored dairy liquid than the current USEPA inventory methods, at least in regions with colder climates.

\section{CONCLUSIONS}

Average $\mathrm{CH}_{4}$ emissions measured from lagoons in southern Idaho ranged from 30 to $126 \mathrm{~kg} / \mathrm{ha}$ per d $(22-517 \mathrm{~kg} / \mathrm{d})$. The factors having the greatest effects on emissions were lagoon physicochemical characteristics, such as VS, pH, and COD, along with events such as pumping, rainfall, high winds, and freezing and thawing, which affected both the rates of diffusion as well as ebullition of $\mathrm{CH}_{4}$ from the lagoons. It was demonstrated that $\mathrm{CH}_{4}$ emissions from these lagoons could be predicted using easily obtained weather data (temperature, wind speed) along with easily determined lagoon characteristics (VS and $\mathrm{pH}$ ), which could enable producers in the region to estimate $\mathrm{CH}_{4}$ emissions from their lagoons. Settling basins, which are commonly used in dairy manure management systems, may produce $50 \%$ of the total lagoon system $\mathrm{CH}_{4}$ emissions and should be accounted for in overall $\mathrm{CH}_{4}$ emissions estimates. The USEPA methodology for estimating $\mathrm{CH}_{4}$ emissions from manure storage underestimated on-farm emissions by $48 \%$. We believe that this is likely due to an underestimation of VS destruction in uncovered anaerobic lagoons. The pattern of seasonal variation in emissions also differed significantly from that estimated with the USEPA methodology; in particular, spring and fall emissions were underestimated with the USEPA method. This seasonality in emissions also underlines the importance of obtaining yearlong data to determine annual emissions estimates and for comparison with inventory methods, as there were times where the USEPA methodology both over- and underestimated emissions. Alternatively, the proposed estimation methodology of Lory et al. (2010) provided a better estimate of on-farm emissions. More work with this alternative methodology should be performed to determine its applicability across a larger range of dairy liquid-storage systems.

\section{ACKNOWLEDGMENTS}

Funding was provided, in part, by the Independent Dairymen's Environmental Action League, Twin Falls, Idaho.

\section{REFERENCES}

Baldé, H., A. C. Vander Zaag, S. Burtt, L. Evans, C. Wagner-Riddle, R. L. Desjardins, and J. D. MacDonald. 2016. Measured versus modeled methane emissions from separated liquid dairy manure show large model underestimates. Agric. Ecosyst. Environ. 230:261-270.

Barton, L. L., and G. D. Fauque. 2009. Biochemistry, physiology and biotechnology of sulfate reducing bacteria. Adv. Appl. Microbiol. 68:41-98.

Bates, D. B., M. Maechler, B. Bolker, and S. Walker. 2015. Fitting linear mixed-effects models using lme4. J. Stat. Softw. 67:1-48.

Bjorneberg, D. L., A. B. Leytem, D. T. Westermann, P. R. Griffiths, L. Shao, and M. J. Pollard. 2009. Measurement of atmospheric ammonia, methane, and nitrous oxide at a concentrated dairy pro- 
duction facility in southern Idaho using open-path FITR spectrometry. Trans. ASABE 52:1749-1756.

Borhan, M. S., S. C. Capareda, S. Mukhtar, W. B. Faulkner, R. McGee, and C. B. Parnell. 2011a. Greenhouse gas emissions from ground level area sources in dairy and cattle feedyard operations. Atmosphere 2:303-329.

Borhan, M. S., S. C. Capareda, S. Mukhtar, W. B. Faulkner, R. McGee, and C. B. Parnell. 2011b. Determining seasonal greenhouse gas emissions from ground-level area sources in a dairy operation in Central Texas. J. Air Waste Manag. Assoc. 61:786-795.

Bryant, M. P., V. H. Varel, R. A. Frobish, and H. R. Isaacson. 1976 Biological potential of thermophilic methanogenesis from cattle wastes. In Seminar on Microbial Energy Conversion. H. G. Schlegel, ed. E. Goltze KG, Gottingen, Germany.

Craggs, R., J. Park, and S. Heubeck. 2008. Methane emissions from anaerobic ponds on a piggery and a dairy farm in New Zealand. Aust. J. Exp. Agric. 48:142-146.

Dungan, R. S., and A. B. Leytem. 2015. Detection of purple sulfur bacteria in purple and non-purple dairy wastewaters. J. Environ. Qual. 44:1550-1555. https://doi.org/10.2134/jeq2015.03.0128.

Eaton, A. D., L. S. Clesceri, E. W. Rice, and A. E. Greenberg, ed. 2005. Standard Methods for the Examination of Water \& Wastewater. 21st ed. American Public Health Association, American Water Works Association, Water Environment Federation. Port City Press, Baltimore, MD.

Flesch, T. K., L. A. Harper, J. M. Powell, and J. D. Wilson. 2009. Inverse-dispersion calculation of ammonia emissions from Wisconsin dairy farms. Trans. ASAE 52:253-265.

Flesch, T. K., S. M. McGinn, D. Chen, J. D. Wilson, and R. L. Desjardins. 2014. Data filtering for inverse dispersion emission calculations. Agric. For. Meteorol. 198-199:1-6.

Flesch, T. K., J. D. Wilson, and L. A. Harper. 2005a. Deducing ground-to-air emissions from observed trace gas concentrations: A field trial with wind disturbances. J. Appl. Meteorol. 44:475-484. https://doi.org/10.1175/JAM2214.1.

Flesch, T. K., J. D. Wilson, L. A. Harper, and B. P. Crenna. 2005b. Estimating gas emissions from a farm with an inverse-dispersion technique. Atmos. Environ. 39:4863-4874. https://doi. org/10.1016/j.atmosenv.2005.04.032.

Flesch, T. K., J. D. Wilson, L. A. Harper, B. P. Crenna, and R. R. Sharpe. 2004. Deducing ground-to-air emissions from observed trace gas concentrations: A field trial. J. Appl. Meteorol. 43:487502 .

Flesch, T. K., J. D. Wilson, L. A. Harper, R. W. Todd, and N. A. Cole. 2007. Determining ammonia emissions from a cattle feedlot with an inversion dispersion technique. Agric. For. Meteorol. 144:139155. https://doi.org/10.1016/j.agrformet.2007.02.006.

Gao, Z., R. L. Desjardins, and T. K. Flesch. 2010. Assessment of the uncertainty of using an inverse-dispersion technique to measure methane emissions from animals in a barn and in a small pen. Atmos. Environ. 44:3128-3134. https://doi.org/10.1016/j. atmosenv.2010.05.032.

Grant, R. H., M. T. Boehm, and B. W. Bogan. 2015. Methane and carbon dioxide emissions from storage facilities at two free-stall dairies. Agric. For. Meteorol. 213:102-113.

Griffiths, P. R., L. Shao, and A. B. Leytem. 2009. Completely automated open path FT-IR spectrometry. Anal. Bioanal. Chem. 393:45-50. https://doi.org/10.1007/s00216-008-2429-6.

Hashimoto, A. G. 1983. Thermophilic and mesophilic anaerobic fermentation of swine manure. Agric. Wastes 6:175-191.

Hashimoto, A. G., Y. R. Chen, and V. H. Varel. 1981. Theoretical aspects of methane production: State of the art. Pages 86-91, 95 in Livestock Waste: A Renewable Resource. Proc. Int. Symp. Livest. Wastes, 4th ed. Amarillo, TX. Apr. 15-17, 1980. ASAE, St. Joseph, MI.

Hastie, T., R. Tibshirani, and J. Friedman. 2009. Elements of Statistical Learning: Data Mining, Inference, and Prediction. 2nd. ed. Springer-Verlag, New York, NY.

Holm, H. W., and J. W. Vennes. 1970. Occurrence of purple sulfur bacteria in a sewage treatment lagoon. Appl. Microbiol. 19:988-996.
Husted, S. 1994. Seasonal variation in methane emission from stored slurry and solid manures. J. Environ. Qual. 23:585-592.

Kaharabata, S. K., and P. H. Schuepp. 1998. Methane emissions from aboveground open manure slurry tanks. Global Biogeochem. $\mathrm{Cy}-$ cles 12:545-554.

Kebreab, E., K. A. Johnson, S. L. Archibeque, D. Pape, and T. Wirth. 2008. Model for estimating enteric methane emissions from United States dairy and feedlot cattle. J. Anim. Sci. 86:2738-2748.

Khan, R. Z., C. Müller, and S. G. Sommer. 1997. Micrometeorological mass balance technique for measuring $\mathrm{CH}_{4}$ emissions from stored cattle slurry. Biol. Fertil. Soils 24:442-444.

Kutner, M., C. Nachtsheim, J. Neter, and W. Li. 2004. Applied Linear Statistical Models. 5th ed. McGraw Hill/Irwin, Chicago, IL.

Leytem, A. B., R. S. Dungan, and D. L. Bjorneberg. 2017. Spatial and temporal variation in physicochemical properties of dairy lagoons in south-central Idaho. Trans. ASABE. In press.

Leytem, A. B., R. S. Dungan, D. L. Bjorneberg, and A. C. Koehn. 2011. Emissions of ammonia, methane, carbon dioxide and nitrous oxide from dairy cattle housing and manure management systems. J. Environ. Qual. 40:1383-1394.

Leytem, A. B., R. S. Dungan, D. L. Bjorneberg, and A. C. Koehn. 2013. Greenhouse gas and ammonia emissions from an openfreestall dairy in southern Idaho. J. Environ. Qual. 42:10-20.

Lory, J. A., R. E. Massey, and J. M. Zulovich. 2010. An evaluation of the USEPA calculations of greenhouse gas emissions from anaerobic lagoons. J. Environ. Qual. 39:776-783

Mangino, J., D. Bartram, and A. Brazy. 2001. Development of a methane conversion factor to estimate emissions from animal waste lagoons. Technical Report. Accessed Jan. 2017. https://www3.epa. gov/ttnchie1/conference/ei11/ammonia/mangino.pdf.

McGinn, S. M., K. A. Beuchemin, and T. K. Flesch. 2009. Performance of a dispersion model to estimate methane loss from cattle in pens. J. Environ. Qual. 38:1796-1802.

Minato, K., Y. Kouda, M. Yamakawa, S. Hara, T. Tamura, and T. Osada. 2013. Determination of GHG and ammonia emissions from stored dairy cattle slurry by using a floating dynamic chamber. Anim. Sci. J. 84:165-177.

Morris, G. R. 1976. Anaerobic fermentation of animal wastes. MS Thesis. Cornell University, Ithaca, NY.

Nunkaew, T., D. Kantachote, T. Nitoda, and H. Kanzaki. 2015. Selection of salt tolerant purple nonsulfur bacteria producing 5-aminolevulinic acid (ALA) and reducing methane emissions from microbial rice straw degradation. Appl. Soil Ecol. 86:113-120.

Okubo, Y., H. Futamata, and A. Hiraishi. 2006. Characterization of phototrophic purple nonsulfur bacteria forming colored microbial mats in a swine wastewater ditch. Appl. Environ. Microbiol. 72:6225-6233

Powers, W., B. Auvermann, N. A. Cole, C. Gooch, R. Grant, J. Hatfield, P. Hunt, K. Johnson, A. Leytem, W. Liao, and J. M. Powell 2014. Chapter 5: Quantifying greenhouse gas sources and sinks in animal production systems. In Quantifying Greenhouse Gas Fluxes in Agriculture and Forestry: Methods for Entity-Scale Inventory. Technical Bulletin Number 1939. M. Eve, D. Pape, M. Flugge, R. Steele, D. Man, M. Riley-Gilbert, and S. Biggar, ed. Office of the Chief Economist, USDA, Washington, DC.

Ro, K. S., and P. G. Hunt. 2006. A new unified equation for wind-driven surficial oxygen transfer into stationary water bodies. Trans. ASABE 49:1615-1622.

Ro, K. S., M. H. Johnson, K. C. Stone, P. G. Hunt, T. Flesch, and R. W. Todd. 2013. Measuring gas emissions from animal waste lagoons with an inverse dispersion technique. Atmos. Environ. 66:101-106.

Rotz, C. A., and D. S. Chianese. 2009. The Dairy Greenhouse Gas Model: Reference Manual. Ver. 1.2. Pasture Systems and Watershed Management Research Unit, Agricultural Research Service, USDA, Washington, DC.

Safley, L. M., Jr., and P. W. Westerman. 1992. Performance of a diary manure anaerobic lagoon. Bioresour. Technol. 42:43-52.

Saggar, S., N. S. Bolan, R. Bhandral, C. B. Hedley, and J. Luo. 2004. A review of emissions of methane, ammonia, and nitrous oxide 
from animal excreta deposition and farm effluent application in grazed pastures. N. Z. J. Agric. Res. 47:513-544.

Sakamoto, Y., M. Ishiguro, and G. Kitagawa. 1986. Akaike Information Criterion Statistics. KTK Scientific Publishers, Tokyo, Japan.

Sejian, V., R. Lal, J. Larkritz, and T. Ezeji. 2011. Measurement and prediction of enteric methane emission. Int. J. Biometeorol. 55:116.

Shao, L., P. R. Griffiths, and A. B. Leytem. 2010. Advances in data processing for open-path fourier transform infrared spectrometry of greenhouse gases. Anal. Chem. 82:8027-8033. https://doi. org/10.1021/ac101711r.

Shao, L., B. Liu, P. R. Griffiths, and A. B. Leytem. 2011. Using multiple calibration sets to improve the quantitative accuracy of partial least squares (PLS) regression on open-path fourier transform infrared (OP/FT-IR) spectra of ammonia over wide concentration ranges. Appl. Spectrosc. 65:820-824.

Shao, L., W. Wang, P. R. Griffiths, and A. B. Leytem. 2013. Increasing the quantitative credibility of open-path Fourier transform infrared (FT-IR) spectroscopic data, with focus on several properties of the background spectrum. Appl. Spectrosc. 67:335-341.

Sommer, S. G., S. O. Petersen, and H. T. Sogaard. 2000. Greenhouse gas emissions from stored livestock slurry. J. Environ. Qual. 29:744-751.

$\mathrm{Su}$, J. J., B. Y. Liu, and Y. C. Chang. 2003. Emission of greenhouse gas from livestock waste and wastewater treatment in Taiwan. Agric. Ecosyst. Environ. 95:253-263.

Todd, R. W., N. A. Cole, K. D. Casey, R. Hagevoort, and B. W. Auvermann. 2011. Methane emissions from southern High Plains dairy wastewater lagoons in the summer. Anim. Feed Sci. Technol. 166-167:575-580.
USEPA. 1993. Method 410.4, Revision 2.0: The determination of chemical oxygen demand by semi-automated colorimetry. Accessed Mar. 2017. https://www.epa.gov/sites/production/files/2015-08/ documents/method_410-4_1993.pdf.

USEPA. 2016a. Annex 3.11. Methodology for estimating $\mathrm{CH}_{4}$ and $\mathrm{N}_{2} \mathrm{O}$ emissions from manure management. Inventory of U.S. greenhouse gas emissions and sinks: 1990-2014. USEPA, Washington, DC, April 2016. Accessed Jan. 2017. https://www.epa.gov/sites/ production/files/2016-04/documents/us-ghg-inventory-2016annex-3-additional-source-or-sink-categories-part-b.pdf.

USEPA. 2016b. Inventory of US Greenhouse Gas Emissions and Sinks 1990-2014. Accessed Sep. 1, 2016. https://www.epa.gov/ ghgemissions/us-greenhouse-gas-inventory-report-1990-2014.

VanderZaag, A. C., T. K. Flesch, R. L. Desjardins, H. Balde, and T. Wright. 2014. Measuring methane emissions from two dairy farms: Seasonal and manure-management effects. Agric. For. Meteorol. 194:259-267.

VanderZaag, A. C. R. J. Gordon, R. C. Jamieson, D. L. Burton, and G. W. Stratton. 2009. Gas emissions from straw covered liquid dairy manure during summer storage and autum agitation. Trans. ASABE 52:599-608.

VanderZaag, A. C., R. J. Gordon, R. C. Jamieson, D. L. Burton, and G. W. Stratton. 2010a. Permeable synthetic covers for controlling emissions from liquid dairy manure. Appl. Eng. Agric. 26:287-297.

VanderZaag, A. C., R. J. Gordon, R. C. Jamieson, D. L. Burton, and G. W. Stratton. 2010b. Effects of winter storage conditions and subsequent agitation on gaseous emissions from liquid dairy manure. Can. J. Soil Sci. 90:229-239.

VanderZaag, A. C. C. Wagner-Riddle, K. H. Park, and R. J. Gordon. 2011. Methane emissions from stored liquid dairy manure in a cold climate. Anim. Feed Sci. Technol. 166-167:581-589.

\section{Appendix}

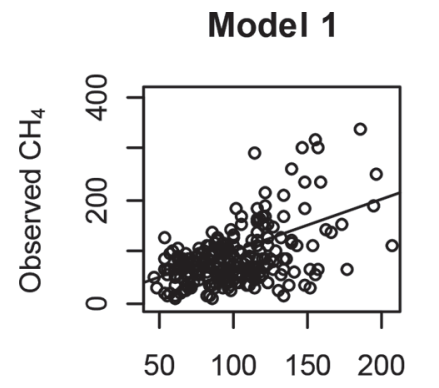

Predicted $\mathrm{CH}_{4}$
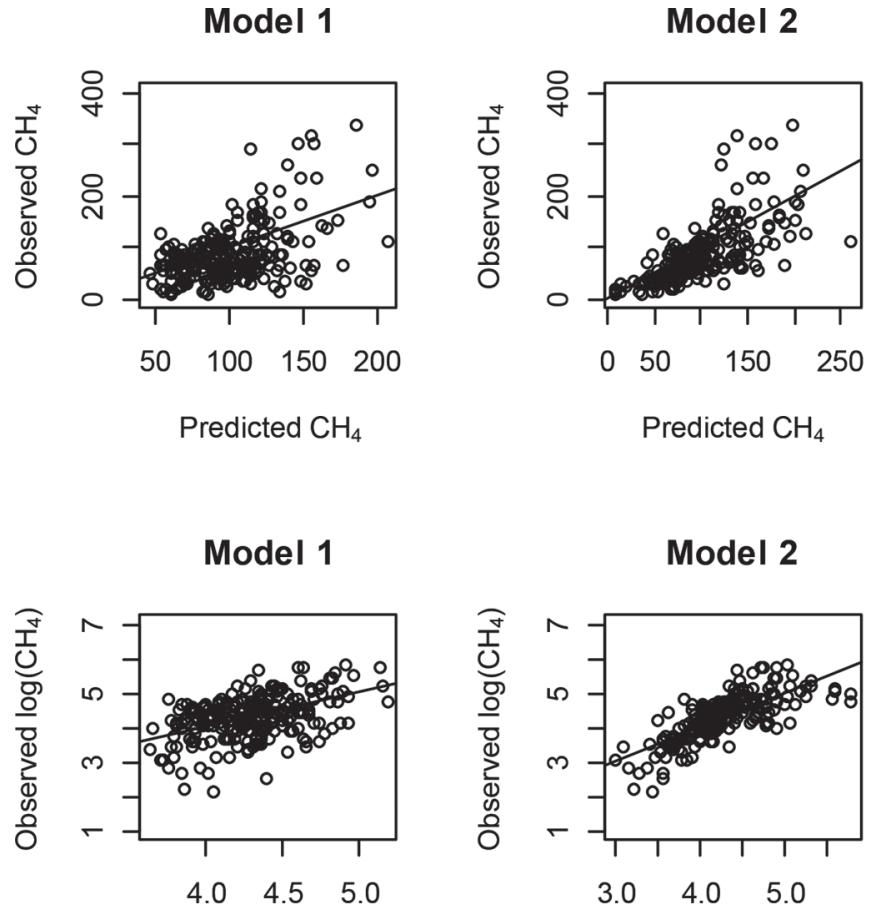

Predicted $\log \left(\mathrm{CH}_{4}\right)$
Model 2

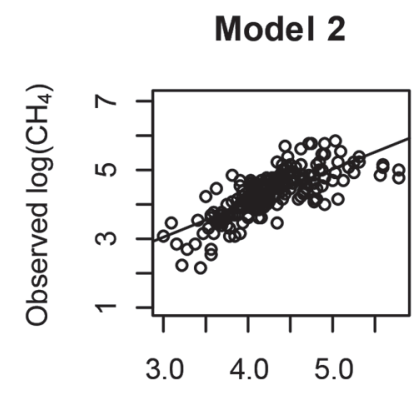

Predicted $\log \left(\mathrm{CH}_{4}\right)$

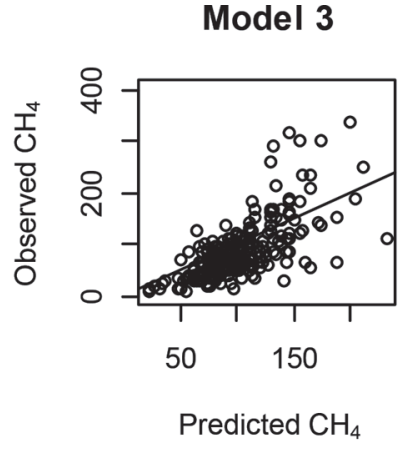

Model 3

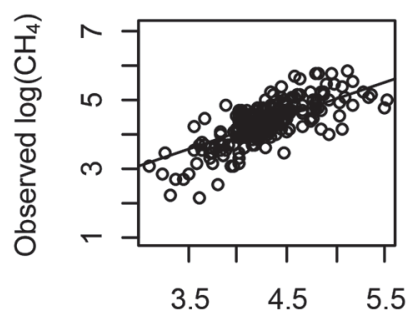

Predicted $\log \left(\mathrm{CH}_{4}\right)$
Model 4

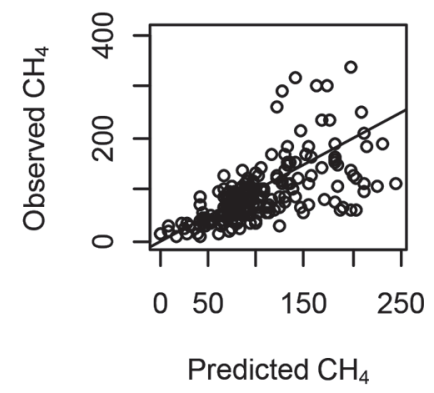

Model 4

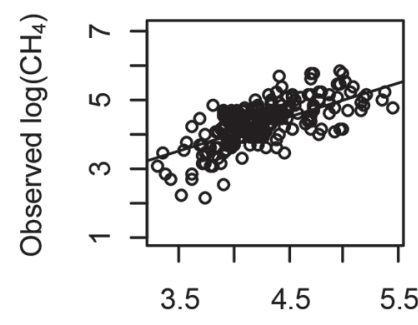

Predicted $\log \left(\mathrm{CH}_{4}\right)$

Figure A1. Observed versus predicted values for the selected methane prediction models in each of the 4 pools of independent variables. The first row has models in the original scale (methane emissions expressed in $\mathrm{kg} / \mathrm{ha} \times \mathrm{d}$ ) and the second row has models fitted with methane emissions in a natural logarithm scale. 
Model 1

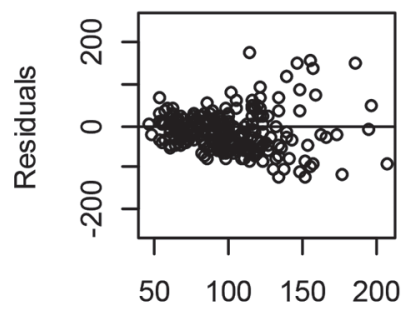

Predicted $\mathrm{CH}_{4}$

Model 1

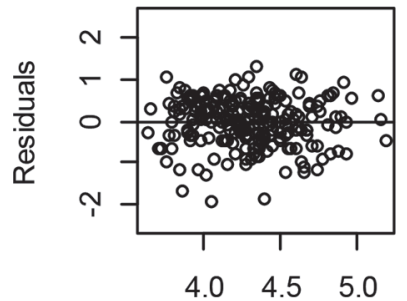

Predicted $\log \left(\mathrm{CH}_{4}\right)$
Model 2

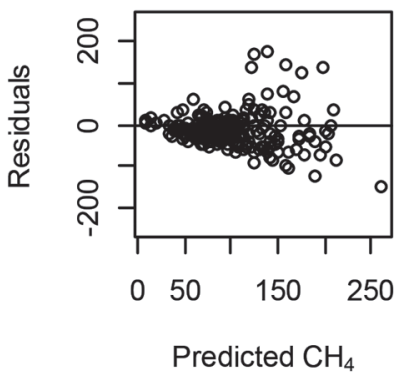

Model 2

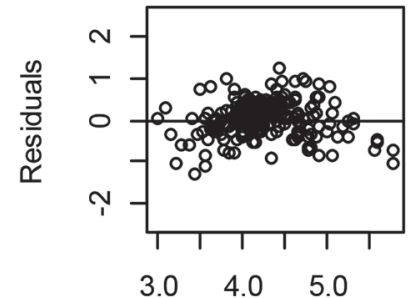

Predicted $\log \left(\mathrm{CH}_{4}\right)$
Model 3

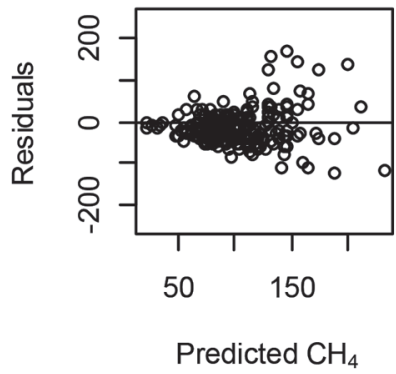

Model 3

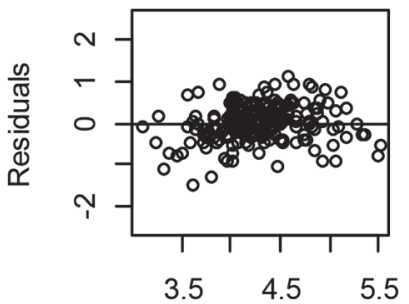

Predicted $\log \left(\mathrm{CH}_{4}\right)$
Model 4

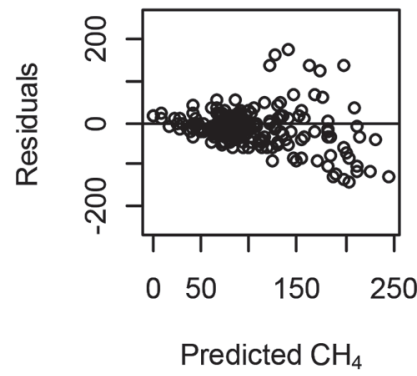

Model 4

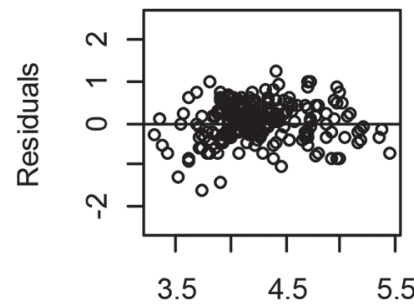

Predicted $\log \left(\mathrm{CH}_{4}\right)$

Figure A2. Residuals versus predicted values for the selected methane prediction models in each of the 4 pools of independent variables. The first row has models in the original scale (methane emissions expressed in $\mathrm{kg} / \mathrm{ha} \times \mathrm{d}$ ) and the second row the models fitted with methane emissions in a natural logarithm scale.

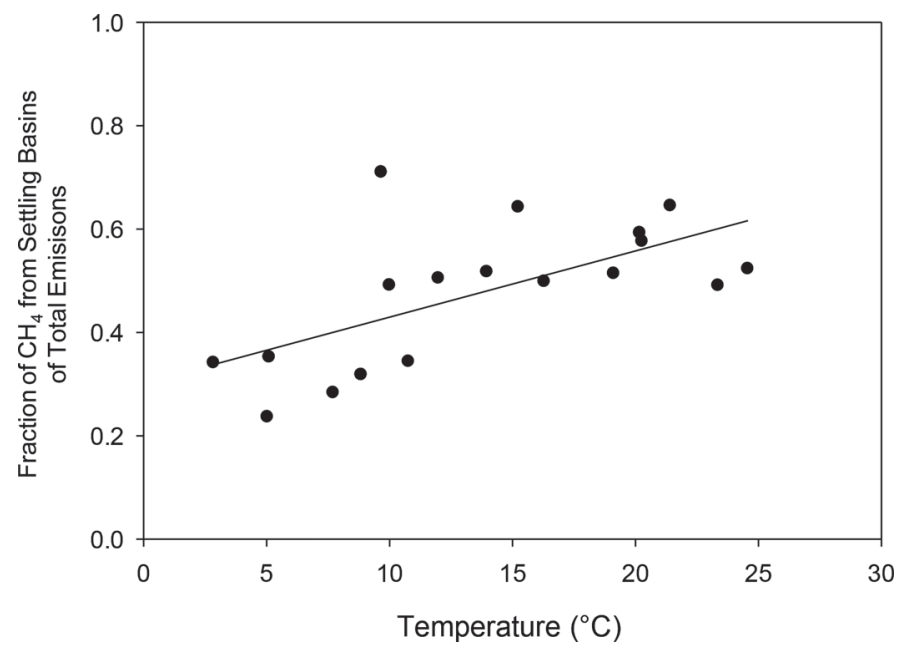

Figure A3. The relationship between the fraction of total methane $\left(\mathrm{CH}_{4}\right)$ produced by the liquid handling system originating from the settling basins and temperature for D3 and D6. 